\title{
'YESTERDAY, I SAW A RABBIT!': UNLEARNT LESSONS FROM THE NOMOS OF THE HOLOCAUST FOR CRIMINOLOGY, OR WHY SOME PRINCIPLES FROM ANARCHISM MAY TRUMP SOVEREIGNTY IN COMBATING GENOCIDE
}

\author{
'ONTEM, EU VI UM COELHO!': LIÇÕES NÃO APRENDIDAS A PARTIR DO \\ NOMOS DO HOLOCAUSTO PARA A CRIMINOLOGIA, OU POR QUE ALGUNS \\ PRINCÍPIOS DO ANARQUISMO PODEM PREPARAR A SOBERANIA PARA \\ COMBATER O GENOCÍDIO
}

\section{‘AAYER, VI UN CONEJO!': LESSIONES NO APREENDIDAS DE LOS NOMOS DEL HOLOCAUSTO PARA LA CRIMINOLOGÍA, O POR QUÉ ALGUNOS PRINCIPIOS DEL ANARQUISMO PUEDEN PREPARAR LA SOBERANÍA PARA EL COMBATE AL GENOCIDIO}

WAYNE MORRISON https://orcid.org/0000-0002-4243-7978 /https://qmul.academia.edu/WayneMorrison/CurriculumVitae / w.morrison@qmul.ac.uk Queen Mary, University of London. London.

\begin{abstract}
Traditional criminology looks to sovereignty and works in defence of social order, thus obedience to the State is a norm, anarchism the enemy. But genocide, as in the Holocaust, presents a different terrain. This article looks at the respective acts and judgments of Otto Ohlendorf and Julius Schmahling within the Nazi nomos. Criminological theory should be alive, human and particular, but aware of its situation in the global and so the article joins with the Jewish Brazilian writer Clarice Lispector to put a dog (or two) in to join the sight of the rabbit that haunted Julius Schmahling and in so doing asks questions on the pedagogy of what is, and/or, should be, Criminology. If this appears historically focussed, the afterword returns us to the present, a time where terrorists claim to fight global wars in the name of purity and security and follow interpretative creeds not dissimilar to Ohlendorf, the final counter-sovereign image is that of the Black Madonna.
\end{abstract}

Keywords: Criminology. Genocide. Nazism. Sovereignty.

\footnotetext{
${ }^{1}$ Material for this article was first presented at a small conference on 'Penal Law, Abolitionism and Anarchism', held in Nottingham by the British/Irish section of the European Group for the Study of Deviance and Social Control in 2014. The perspective on Clarice Lispector was presented at the 2018 conference of the European Group held in Ljublijana, Slovenia, where my dog, Tzu Hsi, was in the audience. In writing this, as increasingly with all I write, I am influenced by the late Nils Christie, whom I studied under for a summer while doing my PHD in the mid 1980's and who deliberately wrote with his personal life story (his location and journey in nomos) in mind and sought to convey his message with candour and simplicity.
} 
'YESTERDAY, I SAW A RABBIT!': UNLEARNT LESSONS FROM THE NOMOS OF THE HOLOCAUST FOR CRIMINOLOGY, OR WHY SOME PRINCIPLES FROM ANARCHISM MAY TRUMP SOVEREIGNTY IN COMBATING GENOCIDE

\section{RESUMO}

A criminologia tradicional responde à soberania e trabalha em defesa da ordem social, de modo que obediência ao Estado é a norma, e anarquismo é o inimigo. Mas o genocídio, como no Holocausto, apresenta um terreno diferente. Esse artigo olha para os atos e julgamentos de, respectivamente, Otto Ohlendorf e Julius Schmahling através do nomos nazista. A teoria criminológica deve estar viva, humana e particular, mas ciente de sua situação no mundo, de modo que o artigo se une à escritora judia brasileira Clarice Lispector para colocar um cachorro (ou dois) para encontrar a visão do coelho que perseguiu Julius Schmahling e, assim o fazendo, questionar sobre a pedagogia do que é e/ou deveria ser a Criminologia. Se isso parece historicamente concentrado, o final nos retorna ao presente, um tempo onde terroristas clamam por lutar guerras globais em nome da pureza e da segurança, seguindo credos interpretativos não diferentes de Ohlendorf, sendo a imagem final contra soberana a da Madonna Negra.

Palavras-chave: Criminologia. Genocídio. Nazismo. Soberania.

\section{RESUMEN}

La criminología tradicional responde a la soberanía y trabaja en la defesa del orden social, así que la obediencia al Estado es norma, y anarquismo es el enemigo. Pero genocidio, así como en el Holocausto, presenta un terreno distinto. Ese trabajo mira a los actos y juicios de, respectivamente, Otto Ohlendorf y Julius Schmahling a través del nomos nazista. La teoría criminológica debe estar viva, humana y particular, pero consciente de su situación en el global, y entonces el articulo se une con la escritora judía brasileña Clarice Lispector para poner un perro (o dos) para juntarse a la percepción del conejo que persiguió Julius Schmahling y, así, cuestionarse sobre la pedagogía de lo que es o podría ser Criminología. Si apareces históricamente concentrado, el final retorna al presente, un tempo donde terroristas quieren luchar una guerra global en favor de la pureza e seguridad, y siguen credos interpretativos no distintos de Ohlendorf, con la imagen final contra soberana de la Madonna Negra.

Palabras clave: Criminología. Genocidio. Nazismo. Soberanía.

\section{SUMMARY}

INTRODUCTION; 1 CONSTITUTING SPACE AND PLACES; 2 PART A: TWO ACTORS; 3 WHY ARE THERE NO DOGS IN OUR CRIMINOLOGY? A QUESTION BY WAY OF CONCLUSION; REFERENCES.

\section{INTRODUCTION}

Political orders are kept secure not only by means of distance from what would destroy them, but sometimes by means of proximity thereto: for when the citizens are afraid, they hold firmly to the political order. Therefore those who think on behalf of the political order must contrive causes of fear, that the citizens may be on guard and like sentries at night do not relax their watch; and they must make what is distant appear to be at hand. ${ }^{2}$

The traditional Eurocentric order of international law is foundering today, as is the old nomos of the earth. This order arose from the legendary and unforeseen discovery of a New World, from an unrepeatable historical event. Only in fantastic parallels can one imagine a modern recurrence, such as men on their way to the moon discovering a new and hitherto

${ }^{2}$ ARISTOTELES. Politics. Oxford: OUP, 1995. 
ISSN 1981-3694

(DOI): $10.5902 / 1981369438100$

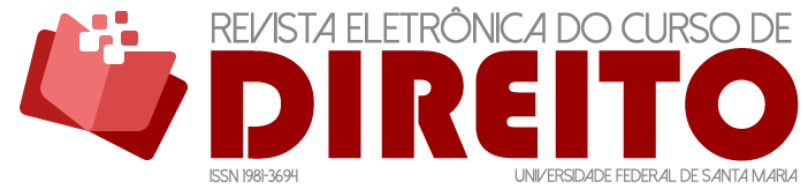

'YESTERDAY, I SAW A RABBIT!': UNLEARNT LESSONS FROM THE NOMOS OF THE HOLOCAUST FOR CRIMINOLOGY, OR WHY SOME PRINCIPLES FROM ANARCHISM MAY TRUMP SOVEREIGNTY IN COMBATING GENOCIDE

WAYNE MORRISON

unknown planet that could be exploited freely and utilized effectively to relieve their struggles on earth.

From the standpoint of the discovered, discovery as such was never legal... Discoveries were made without prior permission of the discovered. Thus, legal title to discoveries lay in higher legitimacy. They could be made only by peoples intellectually and historically advanced enough to apprehend the discovered by superior knowledge and consciousness. To paraphrase one of Bruno Bauer's Hegelian aphorisms: a discoverer is one who knows his prey better than the prey knows himself, and is able to subjugate him by means of superior education and knowledge. $^{3}$

What we have demanded in these trials, where the defendants had committed "legal" crimes, is that human beings are capable of telling right from wrong even when all they had to guide them is their own judgement, which, moreover, happens to be completely at odds with what they must regard as the unanimous opinion of all those around them. And this question is all the more serious as we know that the few who were "arrogant" enough to trust only their own judgement were by no means identical with those persons who continued to abide by old values, or who were guided by a religious belief. Since the whole of respectable society and in one way or another succumbed to Hitler, moral maxims which determine social behaviour and the religious commandments - “Thou shalt not kill!" - which guide conscience had virtually vanished. Those few who were still able to tell right from wrong went really only by their own judgements, and they did so freely; there were no rules to be abided by, under which the particular cases with which they were confronted could be subsumed. They have to decide each instance as it arose, because no rules existed for the unprecedented. ${ }^{4}$

This chapter is constructed as a space opened up by these three quotations; it will people that space with two human actors - Otto Ohlendorf and Julius Schmahling. I will argue that there is a great deal to be learnt for criminology in looking at their respective acts and judgments within what I will term the Nazi nomos. I offer this as a perspective in building criminological theory. Theory, of course, should be alive, human and - dare I say it - particular, but aware of its situation in the global. Often we forget how co-related we are, so I will ultimately join with the Jewish Brazilian writer Clarice Lispector to put a dog (or two) in to join

\footnotetext{
${ }^{3}$ SCHMITT, Carl. The Nomos of the Earth in the International Law of Jus Publicum Europarum. Nova Iorque: Telos Press Publishing, 2003. p. 131-132.

${ }^{4}$ ARENDT, Hannah. Eichmann in Jerusalem: a report on the banality of evil. Harmondsworth: Penguin, 1992. p. 295.
} 
ISSN 1981-3694

(DOI): $10.5902 / 1981369438100$

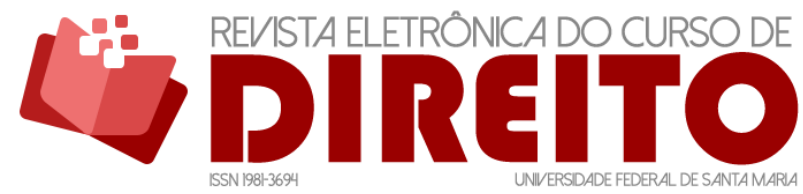

'YESTERDAY, I SAW A RABBIT!': UNLEARNT LESSONS FROM THE NOMOS OF THE HOLOCAUST FOR CRIMINOLOGY, OR WHY SOME PRINCIPLES FROM ANARCHISM MAY TRUMP SOVEREIGNTY IN COMBATING GENOCIDE

WAYNE MORRISON

the sight of the rabbit that haunted Julius Schmahling; in doing so I am asking questions on the pedagogy of what is, and/or what should be, Criminology.

\section{CONSTITUTING SPACE AND PLACES}

What are these quotes and how do they create a space? The first is a statement of the Greek thinker/social activist Aristotle during the foundational period for Western civilization on the role of fear in building political orders and the need for those who wish to control the political order to 'contrive causes of fear' to bind the citizens to the order. The second comes from the post WWII period and is Carl Schmitt on nomos.

Schmitt was a fearsome intellect whose work is shunned by many because of his antiSemitism and his (opportunist) rendering of the Nazi movement as ushered in by historical destiny and thus to be embraced as our fate. In his 1950 opus - simply entitled in the 2003 English translation as The Nomos of the Earth - Schmitt repositioned the term nomos in jurisprudence. Unlike the majority of scholars then (and now!), Schmitt was therein offering a global analysis, perhaps influenced by his prior Catholic readings, and while the Nazi era is not directly referenced in Schmitt's Nomos of the Earth it is possible to see in it a partial explanation of the Nazi project in terms of what had been allowed in the past for European powers (specifically colonial appropriation).

Nomos conventionally referred to the law or principles governing human conduct, Schmitt drew upon its Greek etymology to develop an understanding of something both concrete and transcendental, both law and also pasture, field; division, distribution; district, province. As a jurisprudential-spatial ordering, Nomos was the global structuring which itself contained differing legal, economic and social orders. It was constituted by processes of appropriation, distribution and production ${ }^{5}$.

Through colonialization - backed by western jurisprudence -, the Globe had been subjected to historical appropriation, distribution and production which gave rise to a geographical picture of the contemporary structured by lawfully backed claims to possession, power to defend and normative understanding of friend and enemy. Outside of Europe, the seizure of land had been dependent upon the jurisprudential understanding of the territories to be colonized as 'free space' and resulted in a world spatial order devised, administered and

${ }^{5}$ SCHMITT, Carl. The Nomos of the Earth in the International Law of Jus Publicum Europarum. Nova lorque: Telos Press Publishing, 2003. p. 79. 
ISSN 1981-3694

(DOI): $10.5902 / 1981369438100$

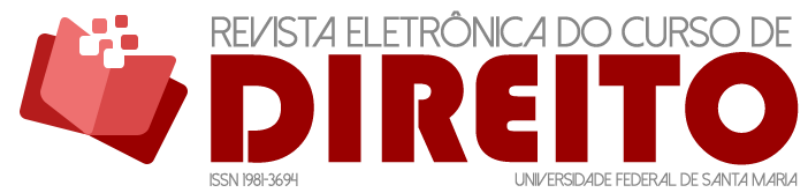

'YESTERDAY, I SAW A RABBIT!': UNLEARNT LESSONS FROM THE NOMOS OF THE HOLOCAUST FOR CRIMINOLOGY, OR WHY SOME PRINCIPLES FROM ANARCHISM MAY TRUMP SOVEREIGNTY IN COMBATING GENOCIDE

WAYNE MORRISON

enforced by Europe in which unregulated war was something that occurred in the rest of the world while war within Europe between 1713 and 1914 grew civilized and increasingly regulated by treaties and alliances.

Although not apparent on a daily basis to its citizens, the entire European state system was dependent upon colonialization and imperialism; at home the rule of law was being built up, in the colonies it was a different zone. This process was also dependent upon dividing humans into the civilized human (the European) and the others (cannibals etc.). Now Schmitt realized a different distinction had been created:

[...] the expulsion of the inhuman from the human was followed in the 19th century by an even deeper division, between the superhuman and the subhuman. Just as the human presuppose the inhuman, so, with dialectical necessity, the superhuman entered history with its hostile twin: the subhuman $\left[\ldots . .{ }^{6}\right.$

Schmitt's spatial ontology was radically indeterminate, linking to the Sovereign and performance: space is always a space of performance. "All law is "situational law". The sovereign produced and guarantees the situation in its totality. He has the monopoly of this last decision"7.

Without having read Schmitt, the Austrian-US sociologist Berger adopts a different interpretation of nomos, in an aptly termed text - The Sacred Canopy ${ }^{8}$ - he depicted the 'human world' as continually needing to be (re)created artificially. Human life faces the constant threat of meaninglessness and needs beliefs, rituals, practices and cultural artefacts that provide an existential comfort that our lives are part of a higher reality, the cohesion of which stems from a cosmic, supra-human ordering principle, which he refers to as a nomos. This nomos is a "shield against terror" and the impact of death is constrained by positing an "individual's life in an allembracing fabric of meanings that, by its very nature, transcends that life" ${ }^{10}$.

\footnotetext{
${ }^{6}$ SCHMITT, Carl. The Nomos of the Earth in the International Law of Jus Publicum Europarum. Nova lorque: Telos Press Publishing, 2003. p. 104.

${ }^{7}$ SCHMITT, Carl. The Nomos of the Earth in the International Law of Jus Publicum Europarum. Nova Iorque: Telos Press Publishing, 2005. p. 13.

8 BERGER, Peter. The Sacred Canopy: elements of a sociological theory of religion. Nova lorque: Doubleday, 1967.

9 BERGER, Peter. The Sacred Canopy: elements of a sociological theory of religion. Nova lorque: Doubleday, 1967. p. 54.

10 BERGER, Peter. The Sacred Canopy: elements of a sociological theory of religion. Nova lorque: Doubleday, 1967. p. 54.
} 
'YESTERDAY, I SAW A RABBIT!': UNLEARNT LESSONS FROM THE NOMOS OF THE HOLOCAUST FOR CRIMINOLOGY, OR WHY SOME PRINCIPLES FROM ANARCHISM MAY TRUMP SOVEREIGNTY IN COMBATING GENOCIDE

By Nomos he understands an ordering in which a "sacred canopy"11 is placed over the abyss of meaningless; chaos threatens nomos. The modern era was an age of revolutions wherein theodicy - the belief in God's plan for existence - was replaced by human positing in which the constituting force was human actions in history. For his part the American liberal legal scholar Robert Cover defines nomos in terms of our everyday reality(s)", as "a normative universe" 12 situated in narratives and "interpretative commitments" 13 that seek the "creation and maintenance of a common life" 14 , a social world. Located in this social order people make decisions, normative decisions, relying on "narratives, experiences and visions [within] which the norm articulated is the right response. Human action is always "stretched between vision and reality" ${ }^{\prime 15}$.

The third comes from Hannah Arendt's famous attempt to understand the grip the Nazi state exerted and the diverse (all-too)human/inhumane (and beyond all previous human understanding) activities constituting what we have come to call the holocaust. While she did not refer to the term Nazi nomos, I would content that this is a fitting expression for what she first presented as a totalitarian world ${ }^{16}$ in which "radical" evil appeared as "normal". Her deliberations in the 1940's and 1950's were scholarly, working through her own personal experience as a Jew forced to leave Europe and searching the resources of classical philosophy and historical experience to make sense of a new phenomenon.

When a few years later she came to observe the trial of Adolf Eichmann in Israel she confronted an existential abyss; while the outcomes were incredibly evil, the actors - here the be-speckled middle aged Eichmann sitting in court behind a bullet proof glass cage - were often banal, exhibiting a strange inability to think broadly while acting with extreme devotion and rationality to their task, what she called acting with a 'thoughtful thoughtlessness'. But if so,

11 BERGER, Peter. The Sacred Canopy: elements of a sociological theory of religion. Nova lorque: Doubleday, 1967. p. 44.

${ }^{12}$ COVER, Robert M.. The Supreme Court, 1982 Term -- Foreword: nomos and narrative. Yale Law School Legal Scholarship Repository, New Haven, v. 2705, n. 1983, p.1-66, 03 maio 2019. Disponível em: <https://digitalcommons.law.yale.edu/fss_papers/2705/>. Acesso em: 03 maio 2019.

${ }^{13}$ COVER, Robert M.. The Supreme Court, 1982 Term -- Foreword: nomos and narrative. Yale Law School Legal Scholarship Repository, New Haven, v. 2705, n. 1983, p.1-66, 03 maio 2019. Disponível em: <https://digitalcommons.law.yale.edu/fss_papers/2705/>. Acesso em: 03 maio 2019.

${ }^{14}$ COVER, Robert M.. The Supreme Court, 1982 Term -- Foreword: nomos and narrative. Yale Law School Legal Scholarship Repository, New Haven, v. 2705, n. 1983, p.1-66, 03 maio 2019. Disponível em: <https://digitalcommons.law.yale.edu/fss_papers/2705/>. Acesso em: 03 maio 2019.

${ }^{15}$ COVER, Robert M.. The Supreme Court, 1982 Term -- Foreword: nomos and narrative. Yale Law School Legal Scholarship Repository, New Haven, v. 2705, n. 1983, p.1-66, 03 maio 2019. Disponível em: <https://digitalcommons.law.yale.edu/fss_papers/2705/>. Acesso em: 03 maio 2019. p. 44

${ }^{16}$ ARENDT, Hannah. The Origins of Totalitarianism. Nova lorque: Sckocken Books, 1958. 
ISSN 1981-3694

(DOI): $10.5902 / 1981369438100$

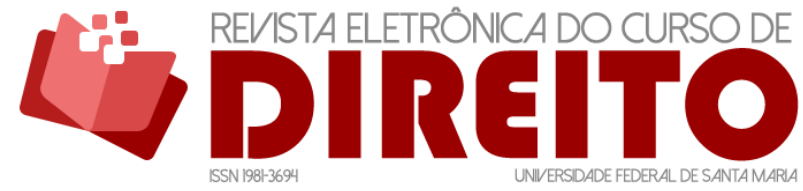

'YESTERDAY, I SAW A RABBIT!': UNLEARNT LESSONS FROM THE NOMOS OF THE HOLOCAUST FOR CRIMINOLOGY, OR WHY SOME PRINCIPLES FROM ANARCHISM MAY TRUMP SOVEREIGNTY IN COMBATING GENOCIDE

WAYNE MORRISON

how were they to be judged guilty and responsible for these massive 'crimes' according to the principles of western jurisprudence that stressed individual responsibility and culpability?

Their human appearance simply did not present a power or a scheming rationality equivalent to the outcomes and their contributory deeds often appeared little more than sitting behind a desk; but the totality of the events seemed to her "to transcend all moral categories and to explode all standards of jurisdiction"17. The State of Israel had made Eichmann a figure of pure evil and sought to link him to all aspects of the Holocaust and to claim that only a Jewish state could defend the Jews who had been forsaken by the world. Arendt felt she had to explode the politics of such a claim which - like the major trial at Nuremberg of the International Military Tribunal which had a focus on waging aggressive war as the main charge - amounted to a defence of State Sovereignty and to powerfully insist that while the holocaust inscribed pain and death on Jewish bodies it was essentially a crime against humankind.

To extend her message: both trials therefore missed the opportunity to move beyond sovereignty and put the question of co-existence in the globe as the central issue. If she though the totalitarian state had brought radical evil she now saw that many of the actors who moved within it were simply banal, and victims often accommodated and made the task easier; all shared in acts of not thinking through the situation. Her deliberations were not met with widespread acclaim; many preferred to see truly evil or sick people, and there was a difficult balancing act in any trial, for legal liberalism worked with individual actors who should and could be held accountable; they needed to be considered as free willed actors who freely chose to do dreadful acts and knew that what they were doing was criminal.

Moreover if the holocaust could be seen as a Jewish issue then it could be safely placed in a - admittedly variable - set of boxes with specific lessons but no general applicability and certainly would only be seen by Jews as the defining moment of modernity. Disciplines such as sociology and criminology could then ignore it and the occasional scholar who argued for its necessary presence as the ghost that haunts late modernity ${ }^{18}$ or the crime of the twentieth century ${ }^{19}$ could be recognizable as... as a Jewish.

So nomos, so the holocaust; but where is the Rabbit, where do the dogs fit in and why do I think this is of concern to criminology?

\footnotetext{
${ }^{17}$ ARENDT, Hannah. Responsability and Judgment. Nova lorque: Sckocken Books, 2003. p. 23.

${ }^{18}$ BAUMAN, Zygmunt. Modernity and the Holocaust. Oxford: Blackwell Publishers, 1989.

19 FRIEDRICHS, David O. The crime of the century?: the case for the holocaust, crime, law \& social Change. [S.l.]: Springer, 2000. p. 21-41.
} 
ISSN 1981-3694

(DOI): $10.5902 / 1981369438100$

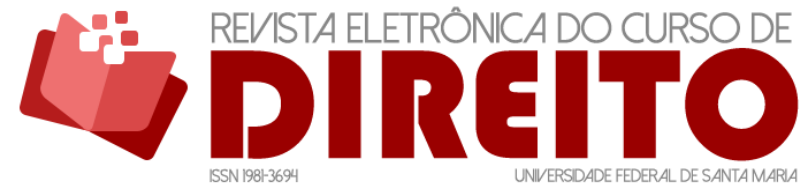

'YESTERDAY, I SAW A RABBIT!': UNLEARNT LESSONS FROM THE NOMOS OF THE HOLOCAUST FOR CRIMINOLOGY, OR WHY SOME PRINCIPLES FROM ANARCHISM MAY TRUMP SOVEREIGNTY IN COMBATING GENOCIDE

At this stage I face a formative issue for when many learn that I teach courses on Law, Modernity and the Holocaust, Jurisprudence and Criminology that are united in a stress on genocide but which refrain from any narrative of psychopaths or evil monsters it is assumed that I am Jewish. When I stress the necessity to face up to the historical presence of genocides which continue (see the fate of the Rohingya in Myanmar in 2017/18) is it then assumed that I am from an 'ethnic minority'. When it is discovered that I am not Jewish but a white, male from the South Island of New Zealand who teaches in a leading law school in London and that I argue that globalization makes redoing the history of our disciplines necessary and that genocide and the holocaust have universal significance, a strange distancing takes place; it's almost a suggestion that something extreme must have happened to me once. 'Why can you not deal with the normal?' as I was once asked. But what is the normal?

Contemporary criminology is without a coherent imagination to position variable mormal(s); that is an essential characteristic of its nomos. In many ways this is welcome and a sign of growing intellectual diversity and - perhaps - maturity in terms of a growing desire for reflexivity, but, and it is a huge BUT, while there are many excellent works in criminology broadly conceived - they fail to break the grip of the mainstream which - particularly in extremely influential American criminology - appears as unimaginative but methodologically focussed, un-reflexive and almost deliberately non-global; is it harsh to call this mindless empiricism? (as per Jock Young 2011, expanding on C. Wright Mills, echoing Ardent).

Most criminology is focused on issues as presented by the nation state and uses data provided by those states. Is it little wonder? Born as part of the supportive gaze of Hobbesian/Westphalian sovereignty criminology was constituted as the rational discourse on crime where crimes were acts or omissions that the state penalized and the state, almost any state, was preferable to non-state existence. Criminology - to use the distinction David Matza ${ }^{20}$ coined - was correctional rather than appreciative: an applied science that did not control its own definitions or ontological base. It accepted that its role was to support the state in modernization processes, to identify the deviant based on a structure whereon the world was divided into civilized space and its other ${ }^{21}$ and never, never engage in a deconstruction of the primacy of the Western state or the idea that social order is based on the contrast with anarchy.

\footnotetext{
${ }^{20}$ MATZA, David. Becoming Deviant. Nova Jérsei: Prentice-Hall, 1969.

21 MORRISON, Wayne. Criminology, Civilisation and the New World Order. Abingdon-on-Thames: Routledge-Cavendish, 2006.
} 
ISSN 1981-3694

(DOI): $10.5902 / 1981369438100$

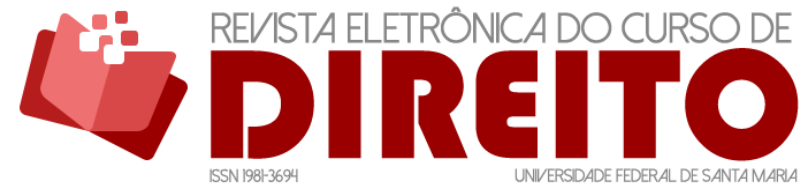

'YESTERDAY, I SAW A RABBIT!': UNLEARNT LESSONS FROM THE NOMOS OF THE HOLOCAUST FOR CRIMINOLOGY, OR WHY SOME PRINCIPLES FROM ANARCHISM MAY TRUMP SOVEREIGNTY IN COMBATING GENOCIDE

WAYNE MORRISON

So do we really need to wonder at the fact that traditional criminology - for example Crime and Human Nature ${ }^{22}$ or A General Theory of Crime ${ }^{23}$ - do not include Genocide or other mass atrocities in their world of facts to be explained? There is much to be learnt: Genocide turns the moral universe that traditional criminology assumes on its head. Traditional criminology accepts sovereignty as the protection against anarchy (Hobbes to Beccaria to rational choice theory), is afraid of 'social disorganization' and considers the normal as the well socialized individual who integrates into the (hierarchical) social order. The criminal is s/he who lacks social and economic capital, who lacks self-control; but in genocide the perpetrator is often an 'ordinary man' (as apparent in the case of Reserve Police Battalion 101 made infamous by the work of Christopher Browning ${ }^{24}$ and Daniel Goldhagen ${ }^{25}$ ) who follows his peer group, who obeys the orders of his institutional and political superiors, or the Eichmann who is ambitious, who is of solid self-control and whose only complaint is that he has not been promoted in line with his responsibilities and achievements.

So what of the core concept of positivist psychology, pathology? The members of Reserve Police Battalion 101 largely resumed their pre-war police careers in post-war Germany. These men who had in face to face conditions went into small towns and villages in occupied Poland rounded up and killed by shooting and throwing into pits over 36,000 unarmed men, women and children, and who had sent another 60,000+ Jews to be transported to their death in various camps, simply fitted into another set of social norms. But for all of this horrific violence they were and they acted as Policemen; so why is it not compulsory to study their story at Police Academies? Is it, perhaps, that genocide and atrocity should very often be explained by situational, or group dynamics of a hierarchical nature? In other words 'in the State we trust'? But if so, then that supposition needs to be the clearly articulated foundational stance (the criminological grundnorm to paraphrase Hans Kelsen) and given the numbers involved, for example the fact that the Holocaust involves the deaths of five and a half centuries of US official homicide (6 million against 1,100,000 in the period 1900 - 2000) then all we should be studying is mass atrocity and the enemy we should be presented with is.... is the State?

\footnotetext{
${ }^{22}$ WILSON, James Q.; HERNSTEIN, Richard J. Crime and Human Nature. Nova lorque: Simon and Schuster, 1985.

${ }^{23}$ GOTTFERSON, Michael; HIRSCHI, Travis. A General Theory of Crime. Stanford: University of California Press, 1990.

${ }^{24}$ BROWNING, Cristopher. Ordinary Men: reserve police battalion 101 and the final solution in Poland. Nova lorque: Harper Collins, 1992.

${ }^{25}$ GOLDHAGEN, Daniel Jonah. Hitler's Willing Executioners: ordinary germans and the holocaust. Nova lorque: Alfred A. Knopf, 1996.
} 


\section{PART A: TWO ACTORS}

Our reading and deliberation should be alive: nomos must be concrete, thus our two individuals. Consider Otto Ohlendorf, which scene should we present? Consider this:

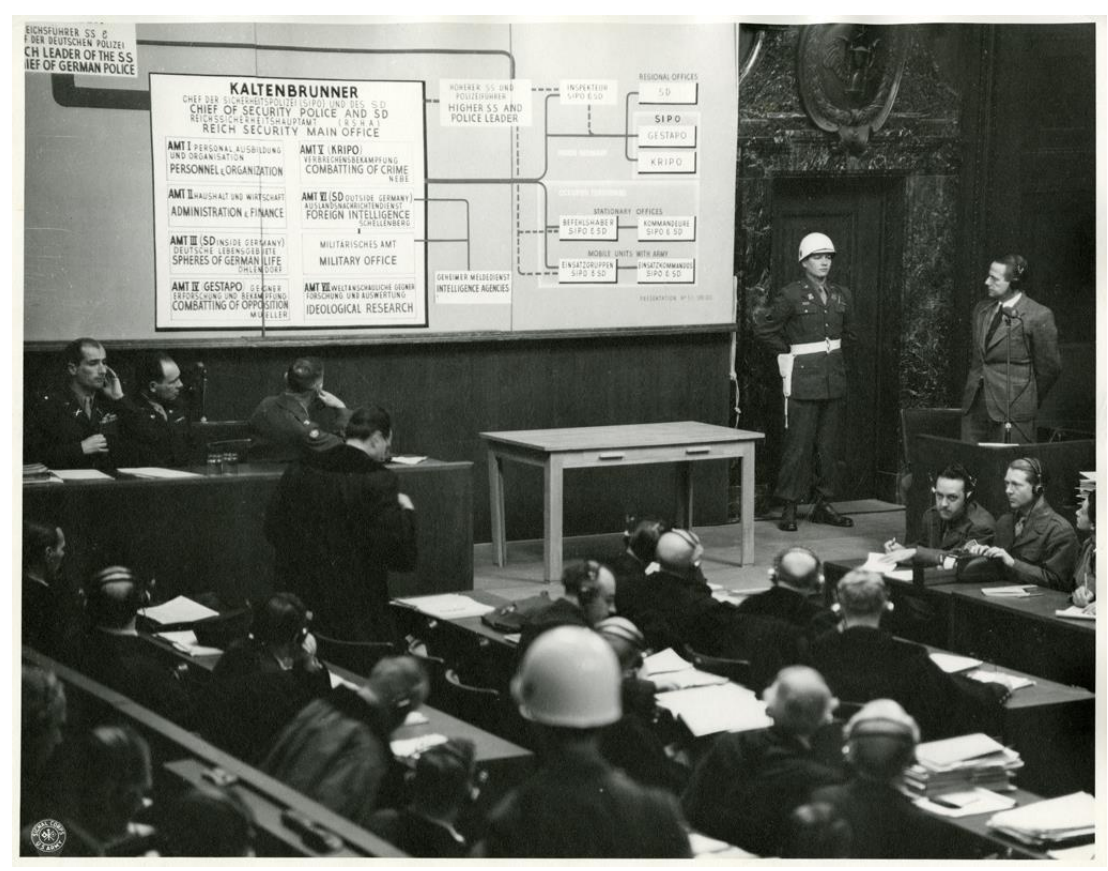

Caption: the 38 year old Otto Ohlendorf, standing in the witness stand with headphones giving evidence at International Military Tribunal at Nuremberg January 3, 1946, a testimony that shocked both the defendants and all who listened; speaking with apparent sincerity and total clarity he explained the structure of the Nazi security apparatus and how he commanded Einsatzgruppen (mobile killing squad) D which exterminated 90,000 Jews and communists by mass shootings or gas-vans in 1941-2.

Or this later extract from the records of a US psychiatrist who ultimately grew exasperated with Ohlendorf's seeming total lack of remorse and apparent failure to face up to what he had been involved with (and thus concluded he was a psychopath).

Q: "What did your Einsatzgruppen do?"

A: "The Jews were shot in a military manner in a cordon. There were fifteen-man firing squads. One bullet per Jew... fifteen Jews at a time. All I had to do was see that it was done as humanely as possible...you will agree it's best to have 
ISSN 1981-3694

(DOI): $10.5902 / 1981369438100$

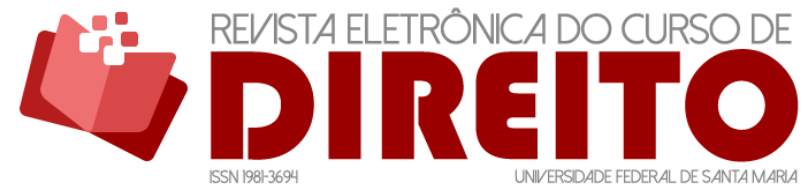

'YESTERDAY, I SAW A RABBIT!': UNLEARNT LESSONS FROM THE NOMOS OF THE HOLOCAUST FOR CRIMINOLOGY, OR WHY SOME PRINCIPLES FROM ANARCHISM MAY TRUMP SOVEREIGNTY IN COMBATING GENOCIDE

good people present to prevent bad executions... Those Jews stood up, were lined up, and were shot in true military fashion. I saw to it that no atrocities or brutalities occurred... I was upset. But it did not interfere with my efficiency and I went on in other fields." 26

Who is this man? Understanding the men (and they were almost entirely men) who made up the direct perpetrators of 'crimes' during the Nazi era has tended to lie in the realms of pathology, or the narrative that Justice Jackson gave to the American people justifying their intervention that the Nazi state was not a real state but a bunch of international brigands who had seized the reins of power and then engaged on a program of terror and through coercion got people to do things they would not otherwise have done, or the banality of evil thesis, or ideas of doubling or split working personalities onto simply opportunity to advance careers etc.

With the exception of Ingrao's important work (aptly entitled Believe and Destroy: Intellectuals in the SS War Machine ${ }^{27}$ ) Ohlendorf, standing as the great example of an intellectual who 'believed' and acted with integrity and candour, has been neglected. Ingroa brings out how Ohlendorf and other 'intellectuals' felt the crisis of Germany in 1919 when not yet or barely a teenager; when Ohlendorf undertook university level study he was presented with a truth, namely that there had been a great betrayal of the German Nation in the military collapse of 1918 and the post WWI treaty of Versailles, a truth that moreover was presented as part of a return to the historical war on the German Reich that had in the thirty years war ended by the Westphalian treaties of 1648 delivered a dethroned rump Germany; so he grew up in a context where the overwhelming messages given to him as reality was that Germany was in crisis and surrounded by enemies and infested with liars, so truth and honor must be rebuilt.

At his later trial Ohlendorf laid out how he always believed in God and looked for a meaningful cosmos. When he turned to National Socialism and joined the NSDAP in 1925 at 18 he did so considering that a real historical answer was being built opposed to the constant threat of anarchy and betrayal of the German Volk. When he later held degrees in Jurisprudence and Economics, having worked as a University lecturer and researcher he embraced being assigned within the SD to the Ministry of Economics. Then came the huge decision: he was seconded to the SS for field action. Why? Perhaps because he complained loudly about corruption in the Nazi party he was assigned to head Einsatzgruppen D; Leo Alexandra summarizes (see discussion in

26 OHLENDORF, Otto. Interview With US Phychiatrist Leon Goldensohne. In: GELLATELY, Robert. The Nuremberg Interview. Nuremberg: Vintage; Reprint Edition, 2007. p. 386-394.

27 INGRAO, Christian. Believe \& Destroy: intellectuals in the SS war machine. Cambridge: Polity, 2013. 
ISSN 1981-3694

(DOI): $10.5902 / 1981369438100$

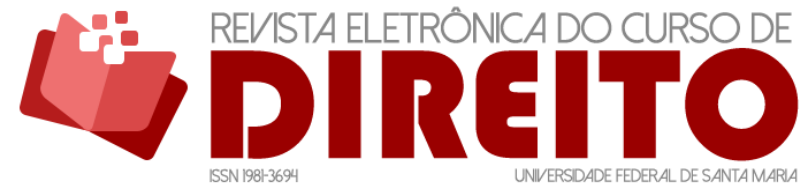

'YESTERDAY, I SAW A RABBIT!': UNLEARNT LESSONS FROM THE NOMOS OF THE HOLOCAUST FOR CRIMINOLOGY, OR WHY SOME PRINCIPLES FROM ANARCHISM MAY TRUMP SOVEREIGNTY IN COMBATING GENOCIDE

WAYNE MORRISON

Wolfe ${ }^{28}$ ) - relying on interviews with Karl Wolff (Chief of Staff to Himmler 1933-43) - that this may have been to morally corrupt him, for it appears that everyone who came into contact with him felt he was an essentially proud and upright man. For Wolff, Ohlendorf was always "an especially decent fellow. An idealist" ${ }^{29}$ with "a blameless past" ${ }^{30}$, an important man whom Himmler thought needed to be 'hardened' and bound to the SS by acts of blutkitt (blood cement). After July 1942 Ohlendorf returned to work on general security and from 1943 on economic matters.

On the day of surrender, May 8, 1945, Ohlendorf was in Flensburg, where Hitler's successor Admiral Karl Donitz had set up headquarters working on plans for new economic agencies to enable the future Germany - under Allied occupation - to flourish and in respect of which he expected himself to head one or other of the new economic organizations. Given that he was particularly versed in intelligence gathering practices in the economic sphere he expected grateful employment: he did not seem to understand that as a high profile Nazi he had no possibility of working for the Anglo-American administration. What was his mind-set?

When the remaining government surrendered to British forces he made no attempt to hide his identity; if that was evidence of his confidence in his ability to sell himself to the new forces what has appeared incredible to many was his subsequent openness and frankness concerning the role of the mobile killing squads and the whole security apparatus of the Nazi state. He was transported almost immediately to London where he quickly provided the British with written and oral information about the Nazi regime although at first not vesting his precise role, however from in mid-august a veritable opening of the floodgates occurred and information about the murder of the Jews flowed. He was the source of the first evidence linking Reinhard Heinrich and his superior SS chief Heinrich Himmler to the implementation of the so-called final solution of the Jewish question.

The British informed American prosecutors that Ohlendorf was a long-standing national socialist and SS commander responsible for mass atrocities in the Crimea but that the British had no plans to prosecute him. The Americans instantly recognized his value as potential prosecution witness and he was transferred back to Germany to the Landsberg prison where Hitler had been held and where he had dictated Mein Kampf. Again he willingly collaborated with the Americans

${ }^{28}$ WOLFE, Robert. Putative Threat to National Security as a Nuremberg Defense for Genocide. Annals: AAPSS, 1980. p. 46-67.

${ }^{29}$ WOLFE, Robert. Putative Threat to National Security as a Nuremberg Defense for Genocide. Annals: AAPSS, 1980. p. 46-67.

${ }^{30}$ WOLFE, Robert. Putative Threat to National Security as a Nuremberg Defense for Genocide. Annals: AAPSS, 1980. p. 46-67. 
ISSN 1981-3694

(DOI): $10.5902 / 1981369438100$

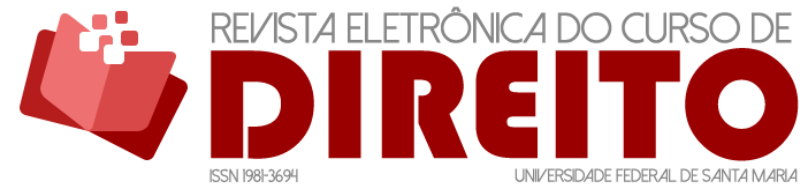

'YESTERDAY, I SAW A RABBIT!': UNLEARNT LESSONS FROM THE NOMOS OF THE HOLOCAUST FOR CRIMINOLOGY, OR WHY SOME PRINCIPLES FROM ANARCHISM MAY TRUMP SOVEREIGNTY IN COMBATING GENOCIDE

WAYNE MORRISON

volunteering information without reservation, in Ingrao's phrase ${ }^{31}$ acting always as an expert witness rather than an accused. His information and testimony made a major impact upon the major trial, that of the International Military Tribunal, but he was not released, instead when it was decided to hold a range of subsidiary trials he became the main defendant in the 'Einsatzgruppen Case', the ninth of twelve trials held by the Americans in their zone of occupation, officially designated United States of America vs. Otto Ohlendorf, et al. (Case No. 9; for a book length treatment see $\operatorname{Earl}^{32}$ ). Twenty-four defendants were charged with criminal conduct arising out of their functions as members of the Einsatzgruppen.

The charges were:

1. Crimes against humanity (including genocide).

2. War crimes.

3. Being members of a criminal organization.

The trial concluded that the primary purpose of the Einsatzgruppen was to accompany the German Army into the occupied East and to exterminate Jews, gypsies, Soviet officials, and other elements of the civilian population regarded as 'racially' inferior or 'Politically undesirable' and that approximately one million humans were victims. This trial was the first to actively use the word genocide and is the only Nuremberg trial specifically focused on the killing of the Jews. Fourteen defendants were sentenced to death by hanging, the others to prison sentences. Faced with a changing political situation and pleas for clemency ten of the death sentences were reduced to prison but Ohlendorf and three others were hung. Historically he was in this unlucky. Most of the other defendants were in time released from prison with their time much shortened. Given that Ohlendorf had provided much of the information that the trail was based on and his role as prosecution witness at the earlier IMT, his execution was almost certainly a breach of due process and procedurally unjust.

The trial was conducted largely in the basis of written reports (including the so-called Einsatzgruppen reports that Ohlendorf had confirmed as genuine). Justice Musmanno, who presided over the trial, wrote that it was difficult to comprehend the events, that there was an instinct to disbelieve, to question, to doubt.

31 INGRAO, Christian. Believe \& Destroy: intellectuals in the SS war machine. Cambridge: Polity, 2013. p. 242.

32 EARL, Hilary. The Nuremberg SS-Einsatzgruppen Trial: 1945-1958. Cambridge: Cambridge University Press, 2009. 
'YESTERDAY, I SAW A RABBIT!': UNLEARNT LESSONS FROM THE NOMOS OF THE HOLOCAUST FOR CRIMINOLOGY, OR WHY SOME PRINCIPLES FROM ANARCHISM MAY TRUMP SOVEREIGNTY IN COMBATING GENOCIDE

There is less of a mental barrier in accepting the weirdest stories of supernatural phenomena, as for instance, water running up hill and trees with roots reaching toward the sky, than in taking at face value these narratives which go beyond the frontiers of human cruelty and savagery. Only the fact that the reports from which we have quoted came from the pens of men within the accused organizations can the human mind be assured that all this actually happened. The reports and the statements of the defendants themselves verify what otherwise would be dismissed as the product of a disordered imagination. ${ }^{33}$

At times during the eight month long trial Ohlendorf grew frustrated, but his resolve and demeanour never collapsed; his claim was simple, he would tell the truth, the absolute truth and not compromise. He was a man of the law and had checked the validity of the orders, he was assured that the orders were ultimately from the Fuehrer, the legitimate head of state, the Sovereign; while he personally did not agree with the orders, the command was that the Jews were to be killed and he had only one choice: commit suicide or obey. He ultimately obeyed but as a man of law he ensured that they were killed with dignity and with honour. He recounted, yet again, how his group minimised the strain of those deaths; he did not allow for example babies to be thrown up into the air and used for bayonet practice, he allowed a mother to hold her baby in such a way that one bullet could kill both in the same action. The Group that he commanded acted in precision, it killed humans not vermin and thus dignity and honour was crucial. His death sentence and execution showed up Ohendorf's tactics as suicidal, but he never compromised.

A crucial scene was when he virtually lectured the presiding prosecutor and judge on the law:

DR. ASCHENAUER: Is, in your opinion, the man who receives these orders obliged to examine them when they are given to him?

DEFENDANT OHLENDORF: This is not possible, legally or actually. According to the general legal interpretation in Germany, not even a judge had the possibility of examining the legality of a law or an order, as little as an administrative official could examine the administrative edict of a supreme authority. But even actually it would have been presumptuous because in the position in which every one of the defendants found themselves, we did not have the possibility of actually judging the situation. It also corresponds to the moral concept which I have learned as a European tradition, that no subordinate can take it upon himself to examine the authority of the supreme commander and chief of state. He only faces his God and history.

33 USA Government Printing Office. Trials of War Criminals Before the Nuremberg Military Tribunals Under Control Council Law No. 10. Volume IV. Washington, D.C., October 1946-April 1949. Disponível em: https://www.loc.gov/rr/frd/Military_Law/pdf/NT_war-criminals_Vol-IV.pdf. Acesso em: 07 maio 2019. p. 450. 
'YESTERDAY, I SAW A RABBIT!': UNLEARNT LESSONS FROM THE NOMOS OF THE HOLOCAUST FOR CRIMINOLOGY, OR WHY SOME PRINCIPLES FROM ANARCHISM MAY TRUMP SOVEREIGNTY IN COMBATING GENOCIDE

Q. Didn't Article 47 of the Military Penal Code give you an occasion to interpret this execution order differently?

A. It is impossible for me to imagine that an article which was created to prevent excesses by individual officers or men leaves open the possibility to consider the supreme order of the supreme commander a crime. Apart from this, again according to continental concept, the chief of state cannot commit a crime.

DR. ASCHENAUER: What is your conviction about the actual background of the Fuehrer order which was given to you?

DEFENDANT OHLENDORF: I have had no cause, and I still have no cause today to think that any other goal was aimed at than the goal of any war, namely, an immediate and permanent security of our own realm against that realm with which the belligerent conflict is taking place.

$\mathrm{Q}$. The prosecution states that the contents of the order and its execution was part of a systematic program of genocide which had as its aim the destruction of foreign peoples and ethnic groups. Will you please comment on this?

A. I did not have any occasion to assume any such plan. I assure you that I neither participated in plans, nor did I see any preparation for such plans which would have let me assume that such a plan existed. What was told to us was our security and those persons who were assumed to be endangering the security were designated as such.

Q. What observations did you yourself make in Russia about the objective prerequisite that the executions of populations, according to the Fuehrer order, were necessary?

A. The experiences in Russia showed me once and for all that here the propaganda of Goebbels had not stated the truth clearly enough. I was convinced that this state, which in order to gain its ends internally, had torn many millions from their families; in the process of separating the-Kulaks [well-to-do farmers] they took the adult population away three times from rural districts. This state would have even less consideration for a foreign population. ${ }^{34}$

As an explanatory frame I use the term Nazi Nomos for the environment in which choices were made - by SS officers and a multitude of others - each choice has individuality, each shares. Nazism at its totality offered a vision for the German community wherein the human (Germanic Volk) was distinct from the subhuman (Jews, Gypsies etc.). For those who believe that language should reflect 'reality' language was debased: 'euphemisms' ${ }^{35}$ operated to detoxify $^{36}$ the task; there were numerous terms for killing without actually using the word; “liquidated", “cleansing, and "evacuations", as Hilberg ${ }^{37}$ said; the Jews were weeds ${ }^{38}$, or a

${ }^{34}$ SCHOOL, Yale Law. Trial of the Major War Criminals Before the International Military Tribunal: Proceedings Volumes (The Avalon Project at the Yale Law School. 2008. p. 247-248. Disponível em: http://avalon.law.yale.edu/subject_menus/imt.asp\#proc. Acesso em: 01 maio 2019.

${ }^{35}$ MITCHELL, Ben; EUTHANASIA, Of Euphemisms And. Of Euphemisms and Euthanasia: The Language Games of the Nazi Doctors and Some Implications for the Modern Euthanasia Movement. In: UNIVERSITY, Wayne State. An International Journal of the Study of Dying, Death, Bereavement, Suicide and Other Lethal Behaviours. [s.l.], 1999.

36 LIFTON, Robert. The Nazi Doctors. London: Macmillan, 1986. p. 202.

${ }^{37}$ HILBERG, Raul. The Destruction of the European Jews. Chicago: Quadrangle Books, 1961.

${ }^{38}$ BAUMAN, Zygmunt. Modernity and the Holocaust. Oxford: Blackwell Publishers, 1989. 
ISSN 1981-3694

(DOI): $10.5902 / 1981369438100$

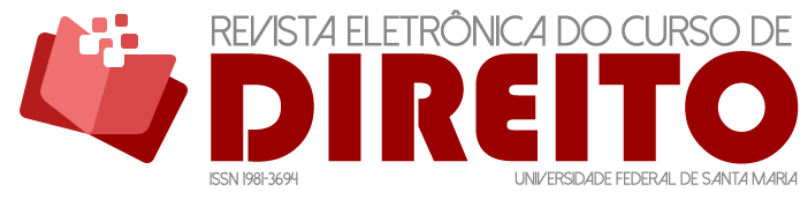

'YESTERDAY, I SAW A RABBIT!': UNLEARNT LESSONS FROM THE NOMOS OF THE HOLOCAUST FOR CRIMINOLOGY, OR WHY SOME PRINCIPLES FROM ANARCHISM MAY TRUMP SOVEREIGNTY IN COMBATING GENOCIDE

WAYNE MORRISON

cancer that had to be removed from society to heal it, images becoming "substitutes" ${ }^{39}$ for the human being, who essentially no longer existed as people; "these are not people being buried, only Jews" ${ }^{40}$. Browning ${ }^{41}$ recounts a memorandum in relation to Jews within the gas vans; "the cargo in the struggle toward the back door" ${ }^{42}$; people are merely cargo and killing is just a process. Perpetrators see themselves as "technicians, soldiers and labourers rather than genocidal killers" 43 , and so they can "deny to themselves and others that people were being killed or injured" ${ }^{44}$.

But Ohlendorf - while showing all the characterizes of the Nazi nomos - never played any games of avoidance; he validated and acknowledged the memo concerning the gas vans and explained the terrible burden his men experienced when opening the vans to see (and smell) the terrible reality of the dead Jewish women and children, for him there was no doubt that the Jews were humans, they were also declared by the Head of State to be the ultimate enemy; he acknowledges time and time again the effect of the killings had on his men. His testimony is perhaps the clearest evidence for the need felt by the Nazi security apparatus to move towards factory style killing in which murders became mundane and "standardized" 45 , but he does not fall into the situation whereby "the victim is truly an outsider who stands alone physically and psychologically" ${ }^{46}$, nor simply state that he as a perpetrator could only see himself as a cog in the vast "machinery of destruction" 47 .

Those who have seriously tried to account for behavior of the perpetrators in the Nazi nomos have stressed various strategies of de-humanization and removal from the 'reality' of the task: thus if each task was spread among the perpetrators - so that they would often be minimal such as booking in inmates - a 'false' vision of bureaucracy is created. And so each could say "[if

\footnotetext{
39 BOSMAJIAN, Haig A. The Language of Oppression. Maryland: American University Press, 1983. p. 25.

40 PERECHODNICK, Calel. Am I a murderer?. Colorado: Westview Press, 1996. p. 55.

${ }^{41}$ BROWNING, Christopher R. Fateful Months: essays on the emergence of the final solution. Nova lorque: Holmes \& Meier, 1985. p. 64-65.

${ }^{42}$ BROWNING, Christopher R. Fateful Months: essays on the emergence of the final solution. Nova lorque: Holmes \& Meier, 1985. p. 64-65.

${ }^{43}$ ALVAREZ, Alexander. Adjusting to Genocide: the techniques of neutralization and the holocaust. [S.l.]: Social Science History Association. 1997. p. 161-162.

${ }^{44}$ ALVAREZ, Alexander. Adjusting to Genocide: the techniques of neutralization and the holocaust. [S.l.]: Social Science History Association. 1997. p. 161-162.

45 HILBERG, Raul. The Destruction of the European Jews. Chicago: Quadrangle Books, 1961. p. 209.

${ }^{46}$ MILGRAM, Stanley. Obedience to Authority. London: Tavistock, 1974. p. 39.

${ }^{47}$ BROWNING, Christopher R. Fateful Months: essays on the emergence of the final solution. Nova lorque: Holmes \& Meier, 1985. p. 7.
} 
ISSN 1981-3694

(DOI): $10.5902 / 1981369438100$

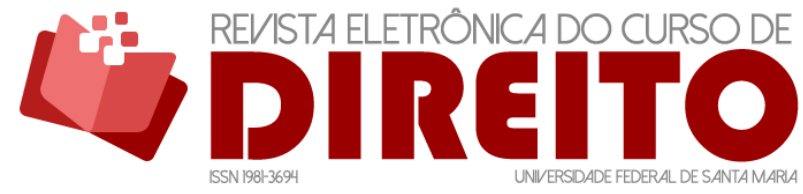

'YESTERDAY, I SAW A RABBIT!': UNLEARNT LESSONS FROM THE NOMOS OF THE HOLOCAUST FOR CRIMINOLOGY, OR WHY SOME PRINCIPLES FROM ANARCHISM MAY TRUMP SOVEREIGNTY IN COMBATING GENOCIDE

WAYNE MORRISON

I] had not killed these inmates, someone else would have"48. But Ohlendorf knows this to be true: he knows it would have made no difference at that stage if he alone had refused the order and committed suicide.

Receiving the order did happen with a hierarchy, it was not that the hierarchy was selfperpetuating as no one felt they were in a position to question the order for he did question it and did discuss it with others, it appeared that it was a valid order from the Sovereign! Browning ${ }^{49}$ seeks to describe this more broadly in terms of belonging to a political project and thus as part of "a continuity and mechanism behind the killing process from which there was no turning back" ${ }^{20}$. Clearly this is correct: to watch Leni Riefenstahl's film the Triumph of the Will, her account of the 1935 Nuremberg party convention where Hess states that 'Germany is Hitler and Hitler is Germany' is to see a visual jurisprudence where total absorption is a reality.

Lesser men, such as Adolf Eichmann: a Nazi SS-Obersturmbannführer (lieutenant colonel) - the classic desk killer - tried to deny their role in killing: "I had nothing to do with the killing [...] once a shipment was delivered to the station [...] my powers ceased"51; he did not pull the trigger or drop in the gas.

In one of the few criminological engagements with the Nazi era Alveraz apples techniques of neutralization, thus Germany was in 'a state of emergency', the Jews threatened the entire pure German nation and had to be stopped: "we are fighting this war for the survival or non-survival of our people" 52 . And semi-eschatological ideology: Hitler combined the fear of the Jew with a beacon of hope for the future. He "Promise[d] the humiliated that they once again could be proud Germans"53; morover this was a strong new legal state, a law based on the pure Volk, and in his relationship to the Volk the Fuhrer voiced the will of this juridical-politicalorganic community: "All that you are, you are through me: all that I am, I am through you alone" ${ }^{24}$. The Volksgemeinschaft saw its pure representation in the apex of absolute

\footnotetext{
48 PENDAS, Devin O. The Frankfurt Auschwitz Trial 1963-1965: Genocide, History and the limits of the law. Nova lorque: Cambridge University Press, 2006. p. 214.

${ }^{49}$ BROWNING, Christopher R. Fateful Months: essays on the emergence of the final solution. Nova lorque: Holmes \& Meier, 1985. p. 87.

${ }^{50}$ BROWNING, Christopher R. Fateful Months: essays on the emergence of the final solution. Nova lorque: Holmes \& Meier, 1985. p. 87.

51 VON LANG, Jochen (Org.). Eichmann Interrogated: transcripts from the archives of Israeli police. The Bodley Head: London, 1983. p. 96.

52 ALVAREZ, Alexander. Adjusting to Genocide: the techniques of neutralization and the holocaust. [S.l.]: Social Science History Association. 1997. p. 164.

${ }^{53}$ BOSMAJIAN, Haig A. The Language of Oppression. Maryland: American University Press, 1983. p. 11.

${ }^{54}$ ARENDT, Hannah. The Origins of Totalitarianism. Nova lorque: Sckocken Books, 1951. p. 462.
} 
ISSN 1981-3694

(DOI): $10.5902 / 1981369438100$

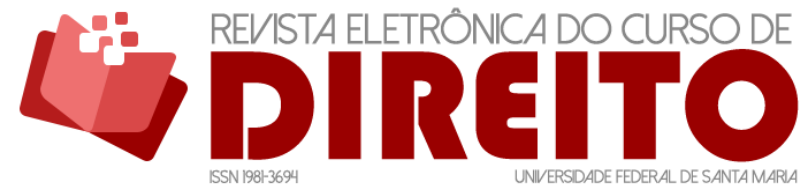

'YESTERDAY, I SAW A RABBIT!': UNLEARNT LESSONS FROM THE NOMOS OF THE HOLOCAUST FOR CRIMINOLOGY, OR WHY SOME PRINCIPLES FROM ANARCHISM MAY TRUMP SOVEREIGNTY IN COMBATING GENOCIDE

WAYNE MORRISON

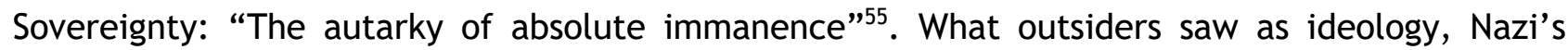
experienced as truth'56. So perpetrators could believe they were on the side of justice, historical destiny.

What of fear? Bauman notes that to base the Nazi order on fear alone, "the SS would have needed more troops, arms and money. Rationality was more effective"57.

It is tempting to consider all of this as an aberration, as perhaps 'true' to the situation of a place outside of time and a time outside of place. When the Nazi state collapsed many felt guilt, evasions were no longer possible and many became desperate; acts of suicide were not uncommon. Only when their normative world was prized apart and spoken about outside its own narrow context were perpetrators able to see how subjective and synthetic it was.

Major Julius Schmahling occupies another form of space and place in the Nazi nomos. His story is virtually unknown; what is told and told repeatedly is how from December 1940 to September 1944, the inhabitants of the French village of Le Chambon-sur-Lignon (population 5.000 ) and the villages on the surrounding plateau (population 24,000) provided refuge for an estimated 5.000 people. This number included an estimated 3.000-3.500 Jews who were fleeing from the Vichy authorities and the Germans.

Under the leadership of Pastor André Trocmé of the Reformed Church of France, his wife Magda, and his assistant, Pastor Edouard Theis, the residents of these villages offered shelter in private homes, in hotels, on farms, and in schools. They forged identification and ration cards for the refugees, and in some cases guided them across the border to neutral Switzerland. These actions of rescue have been celebrated by the State of Israel and France, they are held out as, and indeed are, an outstanding testament to the human spirt and the idea of resistance. They were also a source of amazement to the historian of ethics Philip Hallie who then completed a book on Magda and the village. He concluded that no abstract teaching could have prepared Magda for the acts of compassion and generosity she engaged in, only adopting an ontology of being what you seek to teach, only an epistemology of acting on the level of the everyday face to face; while her husband's acts of help and resistance could be explained as stemming from his belief in the life and death of Jesus, she simply responded to the other's need as placed in her environment.

\footnotetext{
${ }^{55}$ NANCY, Jean-Luc (1991) The Inoperative Community, Minneapolis: University of Minnesota Press, 1991. p. 4.

${ }^{56}$ KOONZ, Claudia. The Nazi Conscience. Massachusetts: Harvard University Press, 2003. p. 2.

${ }^{57}$ BAUMAN, Zygmunt. Modernity and the Holocaust. Oxford: Blackwell Publishers, 1989. p. 203.
} 
ISSN 1981-3694

(DOI): $10.5902 / 1981369438100$

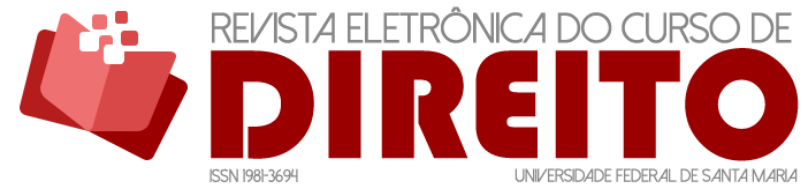

'YESTERDAY, I SAW A RABBIT!': UNLEARNT LESSONS FROM THE NOMOS OF THE HOLOCAUST FOR CRIMINOLOGY, OR WHY SOME PRINCIPLES FROM ANARCHISM MAY TRUMP SOVEREIGNTY IN COMBATING GENOCIDE

WAYNE MORRISON

But Hallie then realised that their actions would not have succeeded if not for a serving member of the German army, Major Julius Schmahling, the German occupation governor of the Haute Loire district in which the villages were located. Although the Nazis replaced him in 1943, he remained second-in-command at his post until the end of the war.

Schmahling knew. Yet he protected the Jews of Le Chambon by failing to report that local villagers were hiding Jews throughout the district, more than that he seems to have been responsible for secret phone calls giving tip offs for raids. Hallie implies that there was a tacit agreement between Schmahling and Trocmé whereby Trocme would seek to minimize violent French resistance activities in the area and Schmahling would covertly protect the villages (and thus the Jews).

Why would a serving German officer take such risks? When Hallie later tracked him down, Schmahling explained his (in)action - which in essence was a very active passiveresistance - in terms of his repugnance at his earlier desire for order as a young teacher; in particular at the ill ease he experienced remembering a specific exchange when he had prepared a lesson on Lions. He was young and wanted to impress; he had prepared a dramatic lesson about the king of beasts, and the classroom was to be a space for his exposition, his personal place of control. But as he spoke the first words, 'The lion is' he noticed a little boy in the back of the room who had been sitting dumbly on his bench during the whole term now waving his hand in the air to catch his eye. The young Schmahling kept talking about the great beasts but a few moments later the boy jumped off his bench and called out 'Herr Professor, Herr-...', Schmahling looked at him in anger - he could not believe that 'this little dunce' was going to interrupt his discourse on lions.

Then the boy did something that really amazed the teacher. He called out, without permission, "Yesterday, yes, yesterday I saw a rabbit. Yesterday I really saw a rabbit.". Before the words were all out, Schmahling yelled out, "Sit down, you little jackass." The boy sat down and never said a word for the rest of the year. ${ }^{58}$

This Schmahling considered was the most decisive event in his whole life. He had acted to crush the boy's spontaneity with all the power of his German pedagogical authoritarianism, and in doing so he was rejecting himself. He was treating the boy as an object of his own performance and acting to reinforce a predestined view of what good order and acceptable speech and manners should be, rather than seeing that as a teacher he should be encouraging

${ }^{58}$ HALLIE, Philip. In the Eye of the Hurricane: tales of good and evil, help and harm. Connecticut: Wesleyan University Press, 1997. p. 77. 
ISSN 1981-3694

(DOI): $10.5902 / 1981369438100$

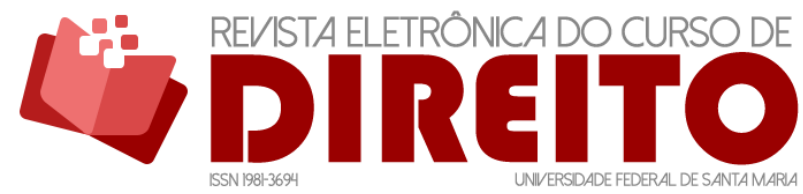

'YESTERDAY, I SAW A RABBIT!': UNLEARNT LESSONS FROM THE NOMOS OF THE HOLOCAUST FOR CRIMINOLOGY, OR WHY SOME PRINCIPLES FROM ANARCHISM MAY TRUMP SOVEREIGNTY IN COMBATING GENOCIDE

WAYNE MORRISON

self-expression and the recognition of others. From that time on teaching and living for him was to change; he vowed that he would from that moment onwards live "making room for each of his students and each of the people he knew outside the classroom to speak about the rabbits, the wonders they had seen" ${ }^{59}$. A anarchical performability was to rule!

By contrast, in seeking to understand how his group of 'intellectuals' came to be so intimately immersed in the 'SS war machine', Ingrao ${ }^{60}$ positions their educational experiences against the idea of a sea of troubles and potential chaos that answers were needed for. In time they became both 'serious students' AND 'Nazi activists'; there was no contradiction as much of the subjects they now studied - law, economics, history, geography, sociology, criminology, anthropology and ethnology - had transformed into 'sciences of legitimation'.

Ultimately, they defended a particular image of order and Sovereignty against the fear of anarchy and strove to redress the (perceived) historical wrongs done to Germany. For these intellectuals, Nazism was a project aiming to realize historical destiny (perhaps God's kingdom on earth). For Schmahling this was the true jackass; he developed into a man of food and drink, of immediate pleasures, resistance to orders - red lights were simply an indication to keep one's eyes open - and joyous support of others. In WWI he had been a very young commissioned officer and throughout the Weimar Republic he had remained in the Army reserves. In the 1930s he had campaigned for the Social Democrats and from 1933 to 1937, when so many Germans were 'coordinated' into supporting the Nazi project, his army reserve status gave him some protection. But he had to survive and under pressure in 1937 he reluctantly joined the Party to keep his teaching job; at least when war came he could be recalled to Army service. Even there, while he was part of a vast machinery of conquest and abuse, he made space for the others and created a place where resistance to the most hideous aspects of the Nazi machine was possible.

So when German rule on France collapsed instead of being tried and convicted by the French he was quietly recognized by them as someone who had been a decent German in trying conditions.

\footnotetext{
59 HALLIE, Philip. In the Eye of the Hurricane: tales of good and evil, help and harm. Connecticut: Wesleyan University Press, 1997. p. 78.

60 INGRAO, Christian. Believe \& Destroy: intellectuals in the SS war machine. Cambridge: Polity, 2013. P. $32-48$.
} 


\section{WHY ARE THERE NO DOGS IN OUR CRIMINOLOGY?}

\section{A QUESTION BY WAY OF CONCLUSION}

I meant by my remark about Kant that the principle of my will must always be such that it can become the principle of general laws. (Eichmann at Trial, claiming he had studied Kant's Kritik der praktischen Vernunft, and had always been a Kantian until he found the reconciliation of his practical reason in aligning it with the will of the Fuhrer) ${ }^{61}$.

I can still reason - I studied mathematics, which is the madness of reason - but now I want the plasma - I want to eat straight from the placenta. ${ }^{62}$

Anarchy. 1539. 1. Absence of government; a state of lawlessness due to the absence or inefficiency of the supreme power; political disorder. 2 transf. Absence or non-recognition of authority in any sphere $1667 .{ }^{63}$

Anarchist: one who objects to the description of 1 and 2 above as necessarily bad or dangerous, instead he/she has an inherent optimism. ${ }^{64}$

The French Jewish philosopher Emmanuel Levinas survived WWII in a Prisoner of War labour camp in Germany after his military unit had been captured in the 'phony war' of 1940. This status of PoWs protected the Jewish soldiers from the full impact of the Holocaust, but Levinas considered it still stripped them of participating in the category of the human:

the other men, the ones we called free, who passed by gave us work, orders or even a smile - and the children and women who also passed by and occasionally looked at us - they all stripped us of our humanity.... With the strength and misery of the persecuted, a small inner voice, in spite of it all, recalled our fundamental essence as thinking human beings. But we were no longer part of the world. ${ }^{65}$

Yet there was one creature that recognised them; one day, purely by chance, a dog wandered into the camp. The prisoners called the dog Bobby, and Bobby got into the habit of

\footnotetext{
${ }^{61}$ ARENDT, Hannah. Eichmann in Jerusalem: a report on the banality of evil, Harmondsworth: Penguin, 1992. p. 136.

62 MOSER, Benjamin. Why this World@ a biography of Clarice Lispector. Harmondsworth: Penguin, 2009. p. 77.

${ }^{63}$ Shorter Oxford Dictionary on Historical Principles. 7th ed, 1959.

${ }^{64}$ BECKMANN, Andrea. Oral interjection to presentation of earlier version of this article. European Group British Conference: Nottingham, 2014.

${ }^{65}$ LEVINAS, Emmanuel. Difficult Freedom: Essays on Judaism, trans. Sean Hand, Baltimore John Hopkins University Press, 1990.
} 
ISSN 1981-3694

(DOI): $10.5902 / 1981369438100$

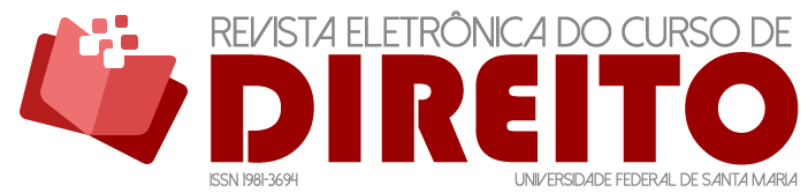

'YESTERDAY, I SAW A RABBIT!': UNLEARNT LESSONS FROM THE NOMOS OF THE HOLOCAUST FOR CRIMINOLOGY, OR WHY SOME PRINCIPLES FROM ANARCHISM MAY TRUMP SOVEREIGNTY IN COMBATING GENOCIDE

WAYNE MORRISON

greeting them with an effusive bark when they lined up in the morning or when they returned from labor at night. Levinas recounts the prisoners' appreciation: 'For him without question - we were men'. ${ }^{66}$ This was not to last, after a few weeks the guards chased the disruptive animal out of the camp and the prisoners saw 'the last Kantian in Nazi Germany' take his leave. It was as if the humans had been stripped of their capacity to be human but yet this dog, without 'the brain power needed to universalize the great principles governing his drives' knew a freedom to judge that the others didn't.

For Levinas ${ }^{67}$, Ardent and other Jewish intellectuals dissipated around the world, the issue of how humanity failed the Jews was crucial; for them a failure to think and strategies of de-humanisation were - among others - at play. No wonder that Ardent was so offended when Eichmann claimed to be a Kantian. Eichmann's version of the Kantian categorical imperative was that his will was most moral when it coincided fully with that of the Fuhrer; in the person of the Fuhrer, as Schmitt and others gave recognition to, was a historical figure who had become the embodiment of the Volk. To align yourself and act and think 'towards the Fuhrer' (to reason such that the Fuhrer would approve of your will) would give the perfect state. So, the battle to say that Eichmann did not think deeply enough, that he sacrificed his 'self' and his individuality to the (perfect) State.

But few could deny that Ohlendorf had continued to think. He knew that he was correct Jurisprudentially, that the law - post Westphalian sovereignty (and as John Austin and Max Weber would state it) - was as he stated it and that the court was making it up. The sovereign power of the state was not accountable in normal operation of law; only in exceptional circumstances of revolution was he called by history to account. The 'truth' of sovereignty had to be denied so that sovereignty could continue.

While intellectuals - Jewish and otherwise - were struggling to provide scholarly language to de justice to the events, in Brazil a young women Clarice Lispector sought to convey another mode of being. Lispector was twice an immigrant: her mother had been raped in an anti-Jewish pogrom in rural Ukraine and suffered syphilis as a result. A folk belief held that pregnancy would cure this and Clarice was born as a pregnancy meant to save her mother - it did not - her mother died when Clarice was c. 9 - and Clarice was to carry an intense form of 'original sin' forever, an immigrant in her own body.

${ }^{66}$ LEVINAS, Emmanuel. Difficult Freedom: Essays on Judaism, trans. Sean Hand, Baltimore John Hopkins University Press, 1990. p. 152-153.

${ }^{67}$ LEVINAS, Emmanuel. Difficult Freedom: Essays on Judaism, trans. Sean Hand, Baltimore John Hopkins University Press, 1990. 
ISSN 1981-3694

(DOI): $10.5902 / 1981369438100$

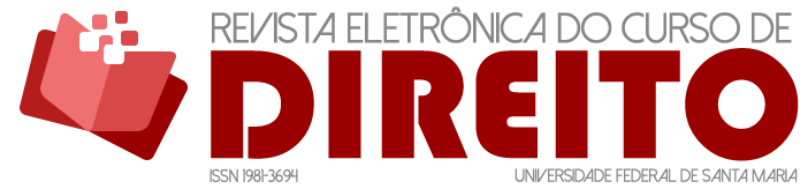

'YESTERDAY, I SAW A RABBIT!': UNLEARNT LESSONS FROM THE NOMOS OF THE HOLOCAUST FOR CRIMINOLOGY, OR WHY SOME PRINCIPLES FROM ANARCHISM MAY TRUMP SOVEREIGNTY IN COMBATING GENOCIDE

WAYNE MORRISON

When a little over a year old, her family immigrated to Brazil to escape further antiJewish actions where her father became a peddler but immersed himself in the small Jewish community. Scholarship, questioning was valued and while not from a wealthy background Clarice inhabited an intellectually challenging environment, went to the best Law School in Brazil and entered journalism. Her constant reflection upon her relationship to Brazil, to herself, her travels (she married a diplomate) and to being as such, came to create a series of existentialist novels and an array of short stories that often verge on the fantastic.

Lispector loved numbers, or rather had a passion for the essence of numbers, numbers, she considered, took us to God. Working with numbers reflects a desire for the pure truth, neutral, unclassifiable and beyond language, the ultimate reality. Mathematics was a formation that bound numbers together, properly used it gave them syntactical meaning. But people abused mathematics; mathematics became a servant of the practical reason of the state and could condemn, assist in rationalizations and betray the human.

'The crime of the mathematics Professor' was written in 1954, the year of the Dictator Vargas's death by suicide. Lispector was at the time the wife of a Brazilian diplomate living in post-war Italy. It is short and dark and the plot seems simple. A mathematics professor has carried a dead dog up a hill and tries to bury it; he digs a shallow grave - pauses and thinks for a while - but then unburies the dog and looks around as if to seek solace but cannot find it.

The intensity of the story comes not from the plot but the self-interrogation of the Professor as he looks at the shallowly buried dog. It transpires that he has only recently come to this town with his family and has left his faithful dog behind, left to wander the streets of his prior town. He feels guilt and tries to make up for his 'crime' by giving the body of a stray dog he has come across a burial. This is meant to be a mathematically equivalent act, but he realizes that his reasoning cannot deliver peace.

Why did he abandon his dog? At first, he gives utilitarian reasons, it would be easier for his wife and family to travel and settle in to the new town without the dog, but realizes the real reason was non-utilitarian, it was a question of power and a response to the demand the dog made of him to live fully and truthfully. He had bought a puppy, had given it a name and 'trained it'. But then the Professor had come to understand that his dog was unconquerable; even when wagging its tail calmly it seemed silently to reject the Professor's power, even the name he had been given.

Although everyone knew it was the Professor's dog, and in that sense an object of property, an object for the Professor to project his dominion onto, the dog had never 
ISSN 1981-3694

(DOI): $10.5902 / 1981369438100$

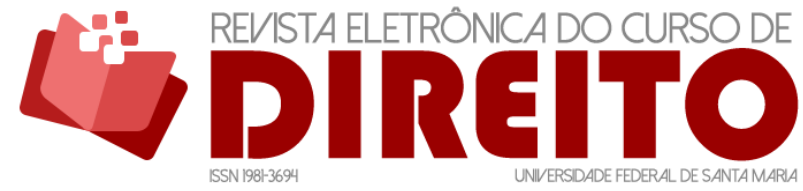

'YESTERDAY, I SAW A RABBIT!': UNLEARNT LESSONS FROM THE NOMOS OF THE HOLOCAUST FOR CRIMINOLOGY, OR WHY SOME PRINCIPLES FROM ANARCHISM MAY TRUMP SOVEREIGNTY IN COMBATING GENOCIDE

WAYNE MORRISON

relinquished, even a little, its past or its nature. And then the Professor came to understand that he did not have to relinquish any part of his own self for the dog to love him. But this realization deeply troubled him for he interpreted this to mean that the dog expected the two of them to reach a mutual understanding on the basis of the resistant reality of their two natures. 'Neither my ferocity nor yours should be changed into gentleness... Without asking for anything, you asked for too much. From you I demanded your being a dog, from me you demanded that I be a man.'

This stirred an innate guilt for the Professor knew he had not sought to live to his potential and could only pretend to be truly human; thus as the dog looked lovingly at him he began to feel as if interrogated. 'I trembled with horror while you were the innocent one.' The dog was innocent, the dog did not even know of its own anguish; the anguish of existing in so perfect the way it had born out its potential. Thus the Professor felt the heavy burden that he become a true man, but he cannot and so he must desert the dog, the dog is 'forsaken'. But then the Professor seems, vaguely, to realize that it is he who is forsaken.

There are so many ways of being guilty of betraying oneself of evading oneself, the Professor vaguely understands, and so he had chosen to hurt the dog by leaving the dog to roam the streets without a home, which he thinks was a petty crime that no one would consign him to hell for doing it. This crime was so small as to be unpunishable. But his act of atonement - to bury the stray dog - is no mathematical or existential equivalent; it fails to give relief, for he realises that what he had done to the dog would be eternally impure. His burying this other dog becomes a non-action, ultimately his original act escapes punishment not in its pettiness but in its magnitude.

There are many modes of interpretation of the story: it is up to your powers of vision and intuition in your nomos. Many see it as an existentialist take on subjectivity; I take it as a critique of the abstract - all too mathematical - reasoning that characterises positivism and mainstream criminology. Lispector wrote it in part when she herself mistakenly gave up her dog, but the story comes out of deeper, more hidden layers of her being. For me, the dog is the Jew, the demand of the dog is the demand for co-existence, the crime of the mathematics Professor is the thousands of small crimes, of acts of judgment of those who turned away and silently acquiesced, of those who did not oppose, of the western countries who refused immigrants, and of the teachers, who unlike what Schmahling became, do not allow Rabbits, or Dogs, in their lessons. 
ISSN 1981-3694

(DOI): $10.5902 / 1981369438100$

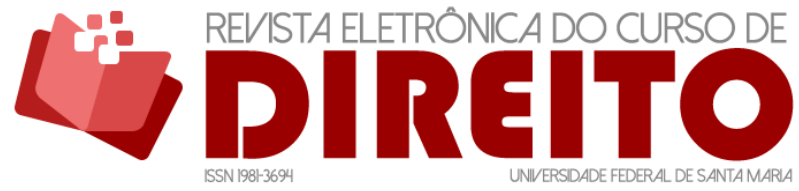

'YESTERDAY, I SAW A RABBIT!': UNLEARNT LESSONS FROM THE NOMOS OF THE HOLOCAUST FOR CRIMINOLOGY, OR WHY SOME PRINCIPLES FROM ANARCHISM MAY TRUMP SOVEREIGNTY IN COMBATING GENOCIDE

WAYNE MORRISON

We all inhabit nomos: particulars in a global. I look back to 13 February 1948, when Ohlendorf made his final statement ${ }^{68}$ before judgment and sentencing. Speaking for over an hour he seemed concerned to provide an explanation for his fellow defendants and Germany as a nation, but also to be a voice of dignity as, he considered, so many fellow German had collapsed under the power of the victors and seemed unable to contest the label of criminals and monsters put on them.

His speech is complex and assertive: National Socialism was not the cause, but the effect of a spiritual crisis. The crisis was caused by the decline of Christian religion, without its eschatological vision man was cast adrift. Chaos threatens, man lacked any 'uniform and firm guiding point' to supply 'motives' and focus; there was no 'idea for learning to live as human beings which was not contested', one seemed doomed to a 'social future... without hope'. What could promise 'true human dignity, firm human objectives, and a spiritual and religious center for their development into human beings?' At that historical point National Socialism arose and was accepted as furnishing the basis of a new order.

To build this new order required real existential commitment: the goal of the Thousand Years Reich demanded that one acted with courage to build and defend that Reich, its spirit and its moral being; bolshevism was the counter 'idol' buttressed by great power, force and martyrs against which they must fight, dealing with conflicting moral and ethical principles but conscious above all to ensure the survival of the nation. Ohlendorf admits that he had feared that those governing Germany invited punishment by their 'frank ignoring of human lives, and of the basic ideas of their own religious and moral conceptions of the people'. But this fear was now overshadowed by a new one, by the fact that the victors seemed not to understand the reality of the historical position. Germans, who had been good citizens, who had acted in the pursuit of their basic conception of law, custom, and morals were now being deprived of their authenticity by the power of the victors who now termed all that they had believed in as 'criminal'. And the WWII victors, who had set up the tribunals at Nuremberg, cast the world struggles in 'oversimplified and over-generalized formulas'.

I confess that I am in agreement with Ohlendorf on that last point - Justice Jackson's beautiful rhetoric of civilization being outraged by the barbaric lawlessness of the Nazi era and that the trials represented Law coming back in to repair the void, was a gross oversimplification

68 USA Government Printing Office. Trials of War Criminals Before the Nuremberg Military Tribunals Under Control Council Law No. 10. Volume IV. Washington, D.C., October 1946-April 1949. Disponível em: https://www.loc.gov/rr/frd/Military_Law/pdf/NT_war-criminals_Vol-IV.pdf. Acesso em: 07 maio 2019. p. 384. 
ISSN 1981-3694

(DOI): $10.5902 / 1981369438100$

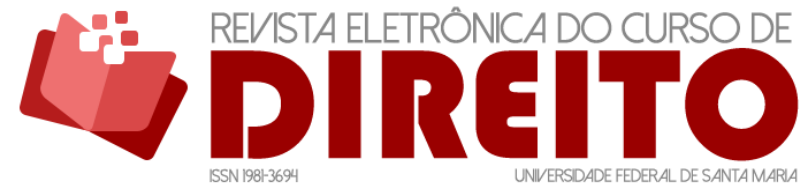

'YESTERDAY, I SAW A RABBIT!': UNLEARNT LESSONS FROM THE NOMOS OF THE HOLOCAUST FOR CRIMINOLOGY, OR WHY SOME PRINCIPLES FROM ANARCHISM MAY TRUMP SOVEREIGNTY IN COMBATING GENOCIDE

WAYNE MORRISON

in that it ignored the vital role of law in National Socialism and the holocaust. And even the attempt to make waging aggressive war the crime of all crimes was victor's justice in that it defended the major principle of inter-State sovereignty - which, as Justice Pal's major dissent in the Tokyo International Military Tribunal argued, would in effect be a defense of European (colonial/imperial) international public law. While the trials were on the one hand relatively fine examples of principled legality their rhetorical justifications were gross oversimplifications which very moreover in line with the assertion of power and epistemology in the service of 'civilization' that had made the nomos of conquest and subjection of peoples around the nonEuropean globe 'legitimate'. Ohlendorf had experienced the horrors of mass bombing by the Allies but knew there were no trials of any of the Allies and now ethnic cleaning was occurring: over 12 million Germans were being expelled from Easter Europe along with mass rapes; Germans were suffering as well.

And if now it was sovereignty was being defended could he and his fellows be guilty? Ohlendorf describes his fellow defendants as having received orders from the highest sources and 'entered on their task convinced that they were backed by a genuine and justified moral force'. Even in the face of personal doubts, they had to act 'because the existence of their people was in deadly peril'. They felt that they had been put into an inevitable, awful, and gigantic war which thrust onto them the role of protective shield for their people. Could they judge the necessity and methods of this war? No. 'They were not responsible and could not be responsible for it.'

After being sentenced to death and after the many appeals to the Americans for leniency in his case were dismissed, on the night before his execution the lead prosecutor Benjamin Ferencz - himself a Jew - visited Ohlendorf in his cell asking if he had any final wishes (and expecting a moment of regret and perhaps messages to go to his wife and family ${ }^{69}$ ).

But Ohlendorf was now bitter - perhaps he could sense that in the early stages of the cold war the mood had firmly turned against punishment of the Nazis, that the need to rebuild (West) Germany for it to be a bulwark against the Soviet Union would mean that most of the commanders of the Einsatzgruppen had their death sentences commuted and, along with those originally sentenced to imprisonment, were released after a few years.

He had been clear: it was the top leaders who should face punishment. In time a revisionist German nationalism would emerge to play off against those who supported the trials

69 STUART, Heikelina Verrijn; SIMONS, Marlise (eds). The Prosecutor and the Judge: Benjamin Ferencz and Antonio Cassese, Interviews and Writings. Amsterdam University Press: Amsterdam, 2009. Disponível em: http://www.benferencz.org/assets/prosecutorjudge.pdf. Acesso em 07 maio 2019. p. 22-23. 
ISSN 1981-3694

(DOI): $10.5902 / 1981369438100$

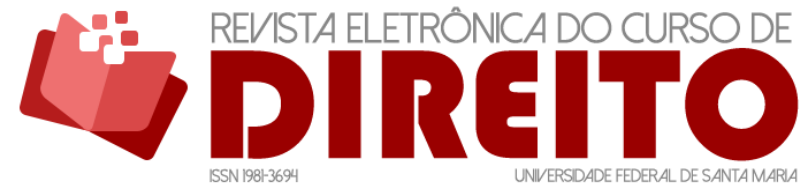

'YESTERDAY, I SAW A RABBIT!': UNLEARNT LESSONS FROM THE NOMOS OF THE HOLOCAUST FOR CRIMINOLOGY, OR WHY SOME PRINCIPLES FROM ANARCHISM MAY TRUMP SOVEREIGNTY IN COMBATING GENOCIDE

WAYNE MORRISON

and those who saw them as a one-sided application of 'justice'; if he had lived he would have participated in diverse and philosophical struggles and his ideologies would have been faced, tested and perhaps overcome. But that was not to happen, Ohlendorf was executed with his position in reality not confronted, hung rather than debated with, so his final words were to the effect that Hitler had probably been right and now he was to die at the bequest of the Jews of New York.

In his 1950 work, Carl Schmitt saw the 'criminalization' (at work in the IMT and subsequent trials) as actions breaking the old nomos but not constituting a new nomos; he warned of instability and predicted a 'global civil war', fought between parties as yet only vaguely discernible, with tropes of the criminal and the inhuman without stable moorings. So selective punishment, one sided culpability; we have moved on, but the ghost of Nuremberg ran through the rhetoric of the U.S. led invasion of Iraq and haunts us today.

We are actors in our nomos, in part, products of our nomos.

I can in a sense divide my life into two phrases: we could call them white settler colonial to the post-colonial, or professionally pre-criminology and with-criminology; alternatively I could describe my own life as the journey to the post religious I was raised in a moderately catholic household in the small town of Timaru in the South Island of New Zealand where my schooling was conducted in Catholic schools; schooling and then Law studies at the University of Canterbury, Christchurch, was a almost exclusively white settler experience, without the self-reflection to realise that.

The legal system and Constitutional Law we were taught was of an unbroken linage from the Common Law of England, there was little mention of the Maori or the Treaty of Waitangi (I describe this in chapter three and elsewhere in The Politics of the Common Law, Adam Geary, Wayne Morrison and Rob, Jago, 2009), after university I travelled and when first came to London worked as a cook and in wine, afterward undertaking post-graduate studies in Criminology and then academic and administrative duties which have taken me to many countries and aroused, to some extent, a global perspective.

Easter Sunday, March 27, 2016, we have a young family friend staying for Easter who is a serving Christian and I have accompanied him to the 11.30 am Mass at the (Roman Catholic) Church of Our Lady of Lourdes, Wanstead, East London, the United Kingdom. The Church is packed to overflowing; entering just on time we have finally found a spot on the end of an aisle in the front row which proved to be a perfect place to view the Master of Ceremonies (Irish) indicating to the various altar servers (young black, white and Asian, boys and girls) and to the 
ISSN 1981-3694

(DOI): $10.5902 / 1981369438100$

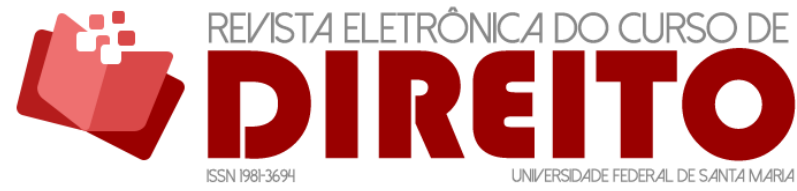

'YESTERDAY, I SAW A RABBIT!': UNLEARNT LESSONS FROM THE NOMOS OF THE HOLOCAUST FOR CRIMINOLOGY, OR WHY SOME PRINCIPLES FROM ANARCHISM MAY TRUMP SOVEREIGNTY IN COMBATING GENOCIDE

WAYNE MORRISON

Priest (an Indian originally from Goa in India) where to stand, and when to move. Various members of the multi-ethnic congregation go up to the altar and do readings, readings from the Gospels telling the story of Easter and the message for the disciples; a story that is about vision and presence.

About Jesus washing the feet of his Apostle's on the Thursday with the message that he who wishes to rule must also be prepared to serve and to 'give his own life as ransom for many' (Matt., 20: 25-28), his betrayal by Judas, the state sanctioned (and voted by the public) putting to death of Jesus on the Friday (a death that Jesus accepts, as in the act of dying he establishes the 'law', a law that is not about the expression of power - admittedly the Old Testament has law that reflects that - but balance, differentiation and yet wholeness) wherein the empirical reality of the Cross confirms the law, the law of sacrifice whereby God sends his son to die on the Cross as symbol of strength through sharing in human weakness, the law that also separates politics from God, his burial and on the Sunday when his tomb is found open and the body missing only for the risen Jesus to present himself, and through recognition of his stigmata (marks from the cross) prove, even to the doubters, that he has conquered death.

The various readings and the short sermon carry messages of humility and of service; serving Christ by working with and in, the poor, to serve Christ by being a vehicle of reconciliation and mutual respect; and the idea of bearing witness, of being a primary witness which meant to be speaking to what you have seen, and a secondary witness, that means to be speaking to what you are a believer in. Some of the latter, I admit, assume a certain image of a 'tranquil soul' assured of salvation by being one who is baptized then a message of peace and reconciliation; the service carries a latent message that dominance will not win, that humble sacrifice is worthy.

As we moved to the back of the Church and on to the procession forward for the host and cup of wine hundreds of miniature candles were being passed from person to person, these, symbolizing the fire (or light) of Christ, would have been the beginning of the ceremony in the midnight Mass. The light, called 'the fire' (for in earliest forms artificial light comes from fire) were a concrete manifestation of presence, the presence that guided the 'lighting', or making clear the truth of material existence, the visualization, and of an energy to find a power of living justly, ethically and with character.

As we walk home I turn to the BBC on my mobile to find the 'breaking news' of a massive suicide bomb set off in a park in Lahore Pakistan which has killed c. 80 and injured c. 300. The Pakistan Taliban are reported as claiming responsibility and state it was aimed at 
ISSN 1981-3694

(DOI): $10.5902 / 1981369438100$

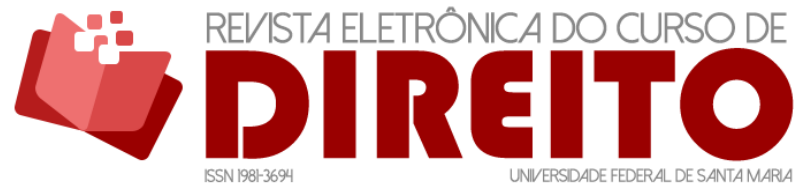

'YESTERDAY, I SAW A RABBIT!': UNLEARNT LESSONS FROM THE NOMOS OF THE HOLOCAUST FOR CRIMINOLOGY, OR WHY SOME PRINCIPLES FROM ANARCHISM MAY TRUMP SOVEREIGNTY IN COMBATING GENOCIDE

killing Christians and ensuring that they leave Muslim soil; many of the victims were families with young children. Immediately I am assailed with images of bodies, children with torn limbs, parents screaming, talk of terrorism, atrocity and mindless destruction and unanswerable questions: 'what kind of people target little children in a park?' The answer was clear from the rhetoric of the killers: to drive the unbelievers from our homeland, to return Pakistan to a land of purity, to ensure that their own children grow up without the sight of the (corrupt) others!

On to 15 March 2019, a lone Australian white male who had been living off and on in Dunedin in the South Island of New Zealand for several years when not travelling the world entered the two relatively new and small Mosques in Christchurch armed with several semiautomatic, military style weapons, and opened fire walking through the two Mosques in a fashion reminiscent of the single shooter Computer war games he claimed to have practiced on, while filming his attack and streaming it live on Facebook. He killed 50 with another 50 hospitalized.

These two small Mosques served an Islamic community of around 4,000 in the Christchurch area (there are c. 4,500 Muslims in New Zealand, c. 1\% of the total population). Christchurch had become more multicultural since I had gone to University there and the constitutional ethos of New Zealand was no longer that of the unproblematic inheritance of Colonial power but of a contested history of legal partnership between settlers and Maori enshrined in the 1840 Treaty of Waitangi.

The attacker had emailed to the authorities only a short time earlier his manifesto: he portrayed himself as a soldier engaged in a global fight back against the invasion by the nonwhite Muslim, a defender of the white race against supposed genocide. Left a small inheritance from his Father, he had left his Australian home town, came to New Zealand but travelled several times to Europe and elsewhere where he claimed to have been shocked by the sight of towns of Southern France in the 'hands of invaders', he then entered into the world of 'dark inter-net', participating in and adding to narratives of global conspiracies, seeking allies to fight against supposed hidden shadowy powers who secretly direct world finances against the beleaguered white race.

He first envisaged attacking in Europe but decided that New Zealand provided numerous soft targets! The New Zealand Prime Minister immediately described the attacks as 'terrorism' and one of New Zealand's 'darkest days', donning a headscarf - she uttered the Islamic words of greeting and of peace in Parliament - and further declared that all members of the Muslim community, previously immigrants, many of whom were refugees in coming to New Zealand, were one of us, thus an attack on you is an attack on all of us. 
ISSN 1981-3694

(DOI): $10.5902 / 1981369438100$

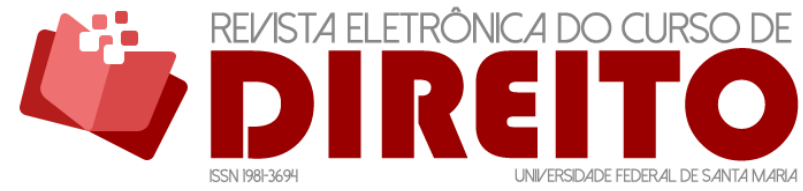

'YESTERDAY, I SAW A RABBIT!': UNLEARNT LESSONS FROM THE NOMOS OF THE HOLOCAUST FOR CRIMINOLOGY, OR WHY SOME PRINCIPLES FROM ANARCHISM MAY TRUMP SOVEREIGNTY IN COMBATING GENOCIDE

WAYNE MORRISON

She was not alone, a massive public outpouring of solidarity was taking place, Maori motorcycle gang members (the most visible on the normal everyday level of anti-social 'others' of the community) hugged Muslim survivors and symbolically guarded the Mosques, many thousands of white, Asian and Maori/Pacific Island women also donned headscarf's and stood in honor symbolically surrounding Muslims at next week's prayer forming a border that was both protection and participant community.

Then April 27, Easter Sunday 2019. I have been at Sacro Monte di Oropa, Northern Italy, an incredible group of buildings, churches and Chapels in alpine setting, once created as a Catholic defense against the Protestant (supposed) invasion of Italy from the north. News comes of the attacks by suicide bombers against three Christian churches and three 'tourist' hotels in Sri Lanka, c. 250 dead, c. 500+ hospitalized. Later Sri Lankan authorities relay claims that this attack was a response to Christchurch and that a message had stated 'this was a present to all Muslim people'!

Where are we? Clarice Lispector, Brazilian Jewish, product of crime, located us halfway up a hill, trying to bury a dead dog that is not our dog to atone for our act of abandonment. Yet we misconstrue this as being about our past mistakes, for it is our continual refusal to rise to the challenge to be fully human - to work out haw to share and co-exist in this world. That hill is always specific, it is where you and I respectively are, yet it is anywhere.

Let us remember, Ohlendorf was not responsible for the holocaust. Yes, he was a clear perpetrator, he failed his test, grievously; but many, many, others failed when faced with lessor dilemmas, they choose not to look, they choose not to make actions in solidarity, and is so doing, they accommodated (and so made it possible!). Like Ohlendorf the contemporary terrorist seeks solace in a system of beliefs providing 'a determinist grip of interpretation,70, in viewing we should not forget the effects of the holocaust, in which the historical ethnic other - the Jews - almost entirely disappeared from Europe. How we view their replacement, the Islamic immigrant, is partially determined by the absence of that other, a failure of solidarity, a failure of care for which those who state that only Israel can defend the Jew, in other words that Sovereignty is the answer taunt all humanity.

Where was I in Easter 2019? I was at Sacro Monte di Oropa, not for any deep religious reason (I am the perfect terrorist target of the post-observer) but to photograph the beautiful sculptured representation of the young Jesus changing water into wine at the marriage feast of

70 INGRAO, Christian. Believe \& Destroy: intellectuals in the SS war machine. Cambridge: Polity, 2013. P.57. 
ISSN 1981-3694

(DOI): $10.5902 / 1981369438100$

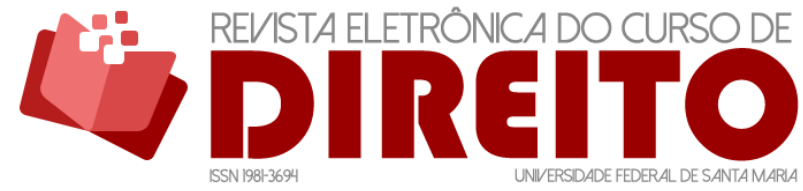

'YESTERDAY, I SAW A RABBIT!': UNLEARNT LESSONS FROM THE NOMOS OF THE HOLOCAUST FOR CRIMINOLOGY, OR WHY SOME PRINCIPLES FROM ANARCHISM MAY TRUMP SOVEREIGNTY IN COMBATING GENOCIDE

WAYNE MORRISON

Cana (Nozze di Cana, Chapel 10). I am working on a book provisionally entitled The Jurisprudence of Wine. I am working on a long story, from belief in the great Sovereign - the God of the Old Testament - to ourselves as metaphysically alone actors in a cosmos that is ours without solace. But always in the human presence of others. I base it on our everyday, as in the company of Julius Schmahling our sharing of wine, that might be water, coffee, tea, might be bread, cava, to see solace as participation in the acts of a humane everyday not obedience to a creed of some grand Sovereign.

And Oropa is a very particular place for it is dedicated to a Black Madonna. There Mary (the earthly Mother of Jesus) is Black, a figure which inter-mixes pagan traditions of the power and fertility of the earth, the Earth Goddess drawing out 'chthonic powers of regeneration', and of the indigenousness population; in a certain respect the Black Madonna is a response to those who created images of the Madonna as pure white.

I had come to find a place of some anarchy within the system! To remember that when the swords and guns of the Europeans conquered the Americas and the Cross accompanied, when dissidents were tortured in the Inquisition to preserve the 'true' interpretation, there were also those who resisted, who subverted, and so we the non-sovereigns, should remember that it is us who must make this a world for our shared future.

\section{REFERENCES}

ALVAREZ, Alexander. Adjusting to Genocide: the techniques of neutralization and the holocaust. [S.l.]: Social Science History Association. 1997.

ARENDT, Hannah. Eichmann in Jerusalem: a report on the banality of evil. Harmondsworth: Penguin, 1992.

ARENDT, Hannah. Responsibility and Judgment. Nova lorque: Sckocken Books, 2003.

ARENDT, Hannah. The Origins of Totalitarianism. Nova lorque: Sckocken Books, 1958.

BAUMAN, Zygmunt. Modernity and the Holocaust. Oxford: Blackwell Publishers, 1989.

BECKMANN, Andrea. Oral interjection to presentation of earlier version of this article. European Group British Conference: Nottingham, 2014.

BERGER, Peter. The Sacred Canopy: elements of a sociological theory of religion. Nova lorque: Doubleday, 1967.

BOSMAJIAN, Haig A. The Language of Oppression. Maryland: American University Press, 1983. 
BROWNING, Christopher R. Fateful Months: essays on the emergence of the final solution. Nova lorque: Holmes \& Meier, 1985.

BROWNING, Cristopher. Ordinary Men: reserve police battalion 101 and the final solution in Poland. Nova lorque: Harper Collins, 1992.

COVER, Robert M.. The Supreme Court, 1982 Term -- Foreword: nomos and narrative. Yale Law School Legal Scholarship Repository, New Haven, v. 2705, n. 1983, p.1-66, 03 maio 2019. Disponível em: <https://digitalcommons.law.yale.edu/fss_papers/2705/>. Acesso em: 03 maio 2019.

EARL, Hilary. The Nuremberg SS-Einsatzgruppen Trial: 1945-1958. Cambridge: Cambridge University Press, 2009.

FRIEDRICHS, David O. The crime of the century?: the case for the holocaust, crime, law \& social Change. [S.l.]: Springer, 2000.

GOLDHAGEN, Daniel Jonah. Hitler's Willing Executioners: ordinary germans and the holocausto. Nova lorque: Alfred A. Knopf, 1996.

GOTTFERSON, Michael; HIRSCHI, Travis. A General Theory of Crime. Stanford: University of California Press, 1990.

HALLIE, Philip. In the Eye of the Hurricane: tales of good and evil, help and harm. Connecticut: Wesleyan University Press, 1997.

HILBERG, Raul. The Destruction of the European Jews. Chicago: Quadrangle Books, 1961.

INGRAO, Christian. Believe \& Destroy: intellectuals in the SS war machine. Cambridge: Polity, 2013.

KOONZ, Claudia. The Nazi Conscience. Massachusetts: Harvard University Press, 2003.

LEVINAS, Emmanuel. Difficult Freedom: Essays on Judaism, trans. Sean Hand, Baltimore John Hopkins University Press, 1990.

LIFTON, Robert. The Nazi Doctors. London: Macmillan, 1986.

LISPECTOR, Clarice. The Crime of the Mathematics Professor. In: Clarice Lispector Complete Stories, Katrina Dobson (trans.) introduction by Benjamin Loser, Harmondsworth: Penguin, 2015, p. 214-221.

MATZA, David. Becoming Deviant. Nova Jérsei: Prentice-Hall, 1969.

MILGRAM, Stanley. Obedience to Authority. London: Tavistock, 1974.

MITCHELL, Ben; EUTHANASIA, Of Euphemisms And. . Of Euphemisms and Euthanasia: The Language Games of the Nazi Doctors and Some Implications for the Modern Euthanasia 
Movement. In: UNIVERSITY, Wayne State. An International Journal of the Study of Dying, Death, Bereavement, Suicide and Other Lethal Behaviours. [s.l.], 1999.

MORRISON, Wayne. Criminology, Civilization and the New World Order. Abingdon-on-Thames: Routledge-Cavendish, 2006.

MOSER, Benjamin. Why this World@ a biography of Clarice Lispector. Harmondsworth: Penguin, 2009.

NANCY, Jean-Luc (1991) The Inoperative Community, Minneapolis: University of Minnesota Press, 1991.

OHLENDORF, Otto. Interview With US Phychiatrist Leon Goldensohne. In: GELLATELY, Robert. The Nuremberg Interview. Nuremberg: Vintage; Reprint Edition, 2007.

PENDAS, Devin O. The Frankfurt Auschwitz Trial 1963-1965: Genocide, History and the limits of the law. Nova lorque: Cambridge University Press, 2006.

PERECHODNICK, Calel. Am I a murderer?. Colorado: Westview Press, 1996.

SCHMITT, Carl. The Nomos of the Earth in the International Law of Jus Publicum Europarum. Nova lorque: Telos Press Publishing, 2005.

SCHOOL, Yale Law. Trial of the Major War Criminals Before the International Military

Tribunal: Proceedings Volumes (The Avalon Project at the Yale Law School. 2008. Disponível em: http://avalon.law.yale.edu/subject_menus/imt.asp\#proc. Acesso em: 01 maio 2019.

STUART, Heikelina Verrijn; SIMONS, Marlise (eds). The Prosecutor and the Judge: Benjamin Ferencz and Antonio Cassese, Interviews and Writings. Amsterdam University Press: Amsterdam, 2009. Disponível em: http://www.benferencz.org/assets/prosecutorjudge.pdf. Acesso em 07 maio 2019.

USA Government Printing Office. Trials of War Criminals Before the Nuremberg Military Tribunals Under Control Council Law No. 10. Volume IV. Washington, D.C., October 1946-April 1949. Disponível em: https://www.loc.gov/rr/frd/Military_Law/pdf/NT_war-criminals_VolIV.pdf. Acesso em: 07 maio 2019.

VON LANG, Jochen (Org.). Eichmann Interrogated: transcripts from the archives of Israeli police. The Bodley Head: London, 1983.

WILSON, James Q.; HERNSTEIN, Richard J. Crime and Human Nature. Nova lorque: Simon and Schuster, 1985.

WOLFE, Robert. Putative Threat to National Security as a Nuremberg Defense for Genocide. Annals: AAPSS, 1980. 
ISSN 1981-3694

(DOI): $10.5902 / 1981369438100$

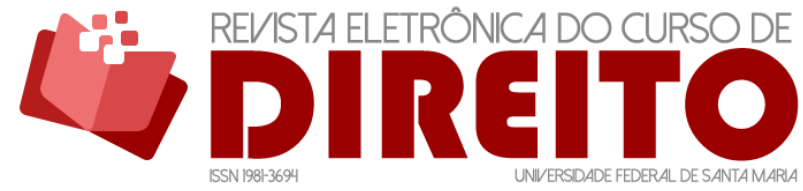

'YESTERDAY, I SAW A RABBIT!': UNLEARNT LESSONS FROM THE NOMOS OF THE HOLOCAUST FOR CRIMINOLOGY, OR WHY SOME PRINCIPLES FROM ANARCHISM MAY TRUMP SOVEREIGNTY IN COMBATING GENOCIDE

Wayne Morrison is Professor of Law at Queen Mary University of London. He writes in areas of Jurisprudence and Criminology and his works have been translated into several languages. He is currently working on two projects: one a reading of Criminology and its avoidance of the global Criminology (not)confonting Globalization and a work that brings Jurisprudence down to earth (literally in the case of terroir!) The Jurisprudence of wine: Explorations in globalization and the normativity of the everyday.

ARTIGO CONVIDADO / INVITED ARTICLE / Publicado em: 10.05.2019 / Published: May 10, 2019

\section{COMO FAZER REFERÊNCIA AO ARTIGO (ABNT/BRASIL) / HOW TO REFER TO THE ARTICLE:}

MORRISON, Wayne. 'Yesterday, i saw a rabbit!': unlearnt lessons from the nomos of the holocaust for criminology, or why some principles from anarchism may trump sovereignty in combating genocide. Revista Eletrônica do Curso de Direito da UFSM, Santa Maria, RS, v. 14, n. 1, e38100, jan./abr. 2019. ISSN 1981-3694. DOI:

http://dx.doi.org/10.5902/1981369438100. Disponível em:

https://periodicos.ufsm.br/revistadireito/article/view/38100 Acesso em: dia mês. ano.

Direitos autorais 2019 Revista Eletrônica do Curso de Direito da UFSM

Editores responsáveis: Rafael Santos de Oliveira e Angela Araujo da Silveira Espindola

Este obra está licenciado com uma Licença Creative Commons Atribuição-NãoComercial-SemDerivações 4.0 Internacional.

\section{SOBRE O AUTOR / ABOUT THE AUTHOR}

WAYNE MORRISON

Professor of Law at Queen Mary University of London. He writes in areas of Jurisprudence and Criminology and his works have been translated into several languages. He is currently working on two projects: one a reading of Criminology and its avoidance of the global Criminology (not)confonting Globalisation and a work that brings Jurisprudence down to earth (literally in the case of terroir!) The Jurisprudence of wine: Explorations in globalisation and the normativity of the everyday. 